\title{
WestVirginiaUniversity
}

THE RESEARCH REPOSITORY @ WVU

Graduate Theses, Dissertations, and Problem Reports

2010

\section{Leaching of chalcopyrite with sodium hypochlorite}

\author{
Ravinder Kumar Garlapalli \\ West Virginia University
}

Follow this and additional works at: https://researchrepository.wvu.edu/etd

\section{Recommended Citation}

Garlapalli, Ravinder Kumar, "Leaching of chalcopyrite with sodium hypochlorite" (2010). Graduate Theses, Dissertations, and Problem Reports. 2146.

https://researchrepository.wvu.edu/etd/2146

This Thesis is protected by copyright and/or related rights. It has been brought to you by the The Research Repository @ WVU with permission from the rights-holder(s). You are free to use this Thesis in any way that is permitted by the copyright and related rights legislation that applies to your use. For other uses you must obtain permission from the rights-holder(s) directly, unless additional rights are indicated by a Creative Commons license in the record and/ or on the work itself. This Thesis has been accepted for inclusion in WVU Graduate Theses, Dissertations, and Problem Reports collection by an authorized administrator of The Research Repository @ WVU. For more information, please contact researchrepository@mail.wvu.edu. 


\title{
Leaching of Chalcopyrite with Sodium hypochlorite
}

\author{
Ravinder Kumar Garlapalli
}

Thesis submitted to the

College of Engineering and Mineral Resources

at West Virginia University

in partial fulfillment of the requirements

for the degree of

\author{
Master of Science \\ in
}

Chemical Engineering

Committee:

Eung Ha Cho, Ph.D., Chair

Ray Y.K. Yang, Ph.D.

John W Zondlo, Ph.D.

\section{Department of Chemical Engineering \\ Morgantown, West Virginia \\ 2010}

Keywords: Chalcopyrite; Copper; Sodium hypochlorite; Hydrometallurgy; Cupric oxide;

Leaching; Reagent consumption ratio. 


\section{Abstract \\ Leaching of Chalcopyrite with Sodium hypochlorite}

\section{Ravinder Kumar Garlapalli}

Chalcopyrite is the most important copper mineral source and also a refractory mineral for leaching. Several processing routes have been proposed to overcome the environmental problems related to copper extraction from chalcopyrite. In this study, the leaching of chalcopyrite has been investigated with a new reagent sodium hypochlorite $(\mathrm{NaOCl})$. Experiments were carried out in two stages: conversion of chalcopyrite to cupric oxide with $\mathrm{NaOCl}$ solution in the first stage, followed by dissolution of the cupric oxide to cupric ion with 1 normal sulfuric acid at room temperature in the second stage. In the first stage leaching, the initial $\mathrm{pH}$ varied from 12.5 to 13.7 ; the temperature, from 35 to $75^{\circ} \mathrm{C} ; \mathrm{NaOCl}$ concentration, from 0.2 to 0.85 molar; and the chalcopyrite dosage, from 1 to 10 grams $/ 500 \mathrm{ml}$. The leaching conversion showed a maximum (68.3\%) around $\mathrm{pH} 13.2$ at 0.5 molar of hypochlorite concentration and $65^{\circ} \mathrm{C}$ in 1 hour. The reagent consumption ratio, defined as the number of moles of hypochlorite consumed to leach one mole of chalcopyrite is found to be much higher than its stoichiometric ratio of 8.5. It reached 57.6 when the solid dosage was 1 gram/500 ml and decreased to 12.9 when the solid dosage was increased to 10 grams $/ 500 \mathrm{ml}$. It was found that the leaching rate of chalcopyrite in the first stage was controlled by chemical reaction with the activation energy of $50.2 \mathrm{~kJ} / \mathrm{mol}$ $(12.0 \mathrm{kcal} / \mathrm{mol})$. A leaching scheme was identified in which $98 \%$ chalcopyrite was leached by adding hypochlorite stock solution stepwise in less than three hours. 


\section{Acknowledgements}

First and foremost, I would like to express my sincere gratitude to my research advisor Dr. Eung Ha Cho, for his guidance, support and timely help extended throughout this project. His unrelenting pursuit to see the work through and guide all of his students beyond graduation is evident and much appreciated.

I would like to thank my committee members Dr. John W. Zondlo and Dr. Ray Y. K. Yang for accepting to serve on my thesis committee and for their valuable suggestions and comments on my thesis. I also thank the Faculty and Staff of the Department of Chemical Engineering for the help and support provided for this project.

Beyond the educational and technical guidance, I am extremely thankful to my parents, Mr. G. Jagadeshwar and Mrs. G. Krishnaveni, and my family members for always being with me and believing in whatever I do. I also thank all my friends for their help and making this period of my stay memorable.

Finally, I would like to thank the Center for Advanced Separation Technologies (CAST), NETL/DOE for financial support under grant CR-19147-A-4929231, which made this project possible. 


\section{Table of Contents}

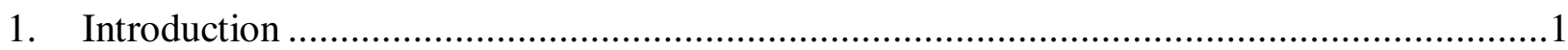

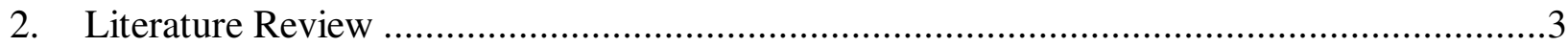

2.1 Research Work.......................................................................................

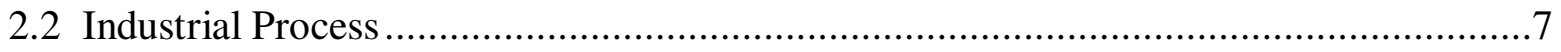

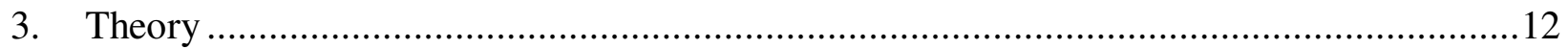

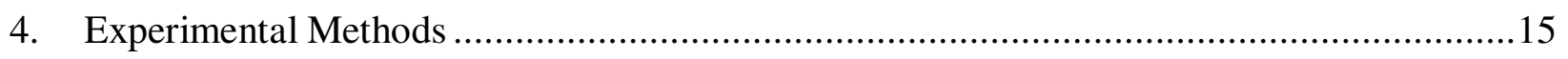

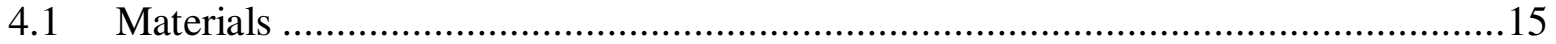

4.2 Leaching experiments with hypochlorite ...................................................... 15

4.3 Leaching Experiments with Sulfuric Acid............................................... 17

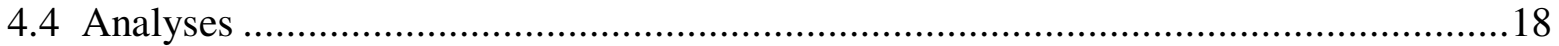

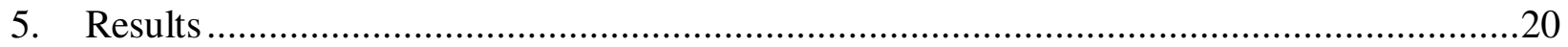

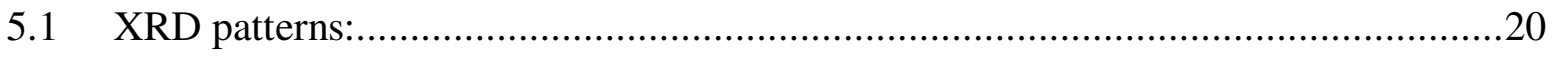

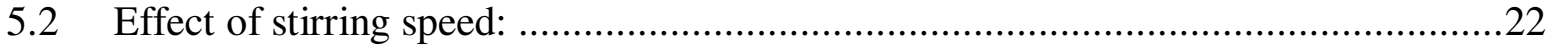

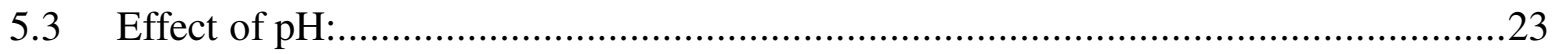

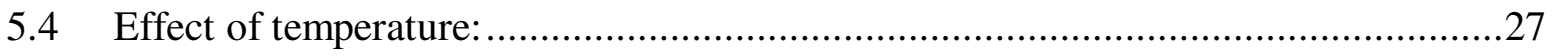

5.5 Effect of Hypochlorite concentration: ..................................................... 30

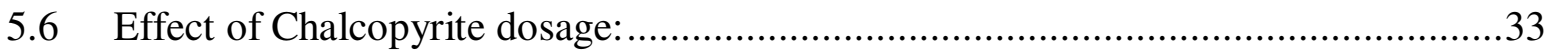

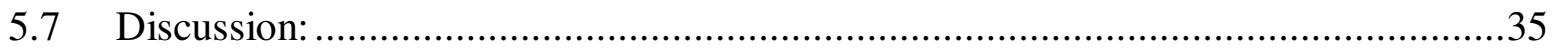

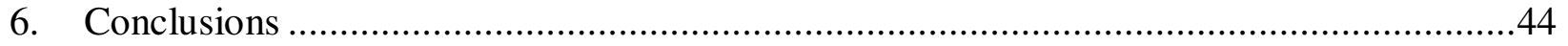

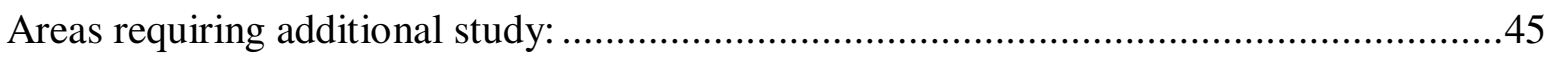

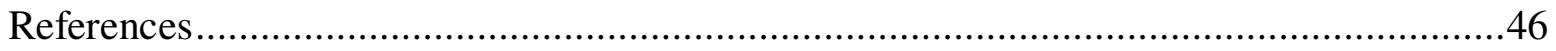




\section{List of Figures}

Figure 2. 1 World copper production since 1981-2005 (Data from Edeltein5 for the years 19812000 and from the International Copper Study Group6 for the years 2001- 2005)...................3

Figure 4. 1 Schematic diagram of leaching apparatus. .............................................. 16

Figure 5.1 X-Ray diffraction spectra of the unleached chalcopyrite mineral sample.................20

Figure 5.2 X-Ray diffraction spectra of the leached chalcopyrite sample after first stage of

leaching $\left(55^{\circ} \mathrm{C}, 0.5\right.$ molar $\mathrm{OCl}-, 3$ grams chalcopyrite, initial $\left.\mathrm{pH} 13.15\right)$.

Figure 5.3 Effect of stirring speed on leaching conversion of chalcopyrite $\left(85^{\circ} \mathrm{C}\right.$, hypochlorite

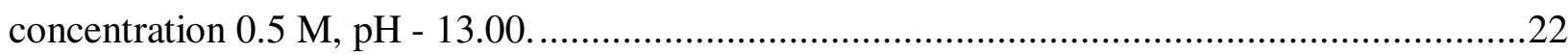

Figure 5.4 Effect of initial $\mathrm{pH}$ on chalcopyrite leaching conversion $\left(55^{\circ} \mathrm{C}, 0.5\right.$ molar $\mathrm{OCl}-, 3$

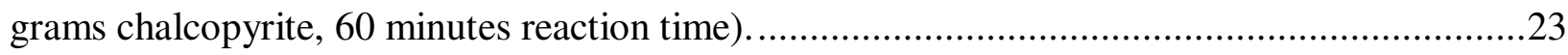

Figure 5.5 Effect of $\mathrm{pH}$ on hypochlorite depletion $\left(55^{\circ} \mathrm{C}, 0.5\right.$ molar $\mathrm{OCl}-, 3$ grams chalcopyrite).

Figure 5.6 Effect of temperature on chalcopyrite leaching conversion (0.5 molar OCl-, 3 grams

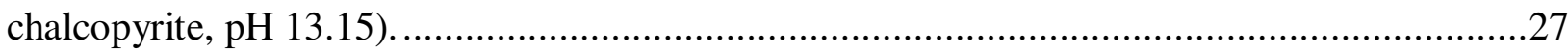

Figure 5.7 Effect of temperature on hypochlorite depletion (0.5 molar OCl-, 3 grams

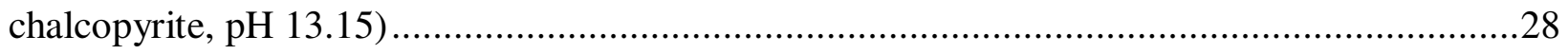

Figure 5.8 Effect of temperature on reagent consumption ratio $\left(55^{\circ} \mathrm{C}, 3\right.$ grams chalcopyrite,

initial $\mathrm{pH} 13.15)$.

Figure 5.9 Effect of hypochlorite concentration on chalcopyrite leaching conversion $\left(55^{\circ} \mathrm{C}, 3\right.$

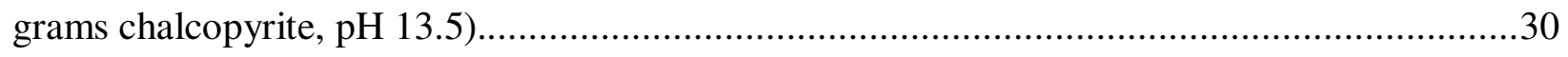

Figure 5.10 Depletion of hypochlorite concentration at various initial concentrations $\left(55^{\circ} \mathrm{C}, 3\right.$

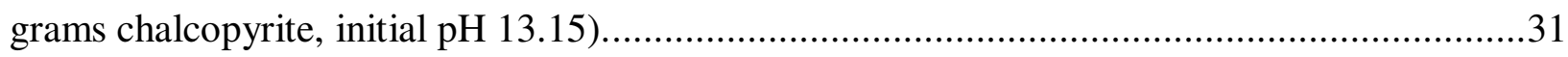


Figure 5.11 Effect of initial hypochlorite concentration on reagent consumption ratio at 60

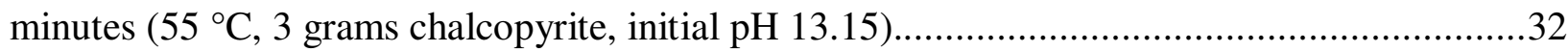

Figure 5.12 Effect of chalcopyrite dosage on leaching conversion at 60 minutes $\left(55^{\circ} \mathrm{C}, 0.5\right.$ molar OCl-, initial pH 13.15).

Figure 5.13 Effect of chalcopyrite dosage on hypochlorite consumption ratio at 60 minutes (55 ${ }^{\circ} \mathrm{C}, 0.5$ molar $\mathrm{OCl}^{-}$, initial $\left.\mathrm{pH} 13.15\right)$.

Figure 5. 14 Leaching conversion of chalcopyrite with stepwise addition of hypochlorite $\left(55^{\circ} \mathrm{C}\right.$,

$\mathrm{pH}$ 13.2, 10 grams chalcopyrite).

Figure 5.15 Comparison of surface reaction control model fitting for first and half orders with respect to hypochlorite concentration $\left(55^{\circ} \mathrm{C}, 3\right.$ grams chalcopyrite, initial $\left.\mathrm{pH} 13.15\right)$. Figure 5.16 Arrhenius plot for chalcopyrite leaching with hypochlorite (0.5 molar $\mathrm{OCl}^{-}, 3$ grams chalcopyrite, initial $\mathrm{pH} 13.15$ ) 


\section{List of Tables}

Table 5. 1 Effect of $\mathrm{pH}$ on Leaching of Chalcopyrite in First Stage $\left(55^{\circ} \mathrm{C}, 0.5\right.$ molar $\mathrm{OCl}$,

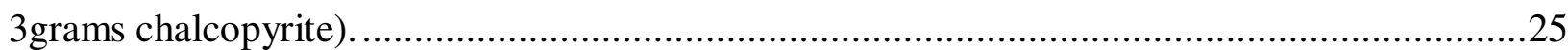

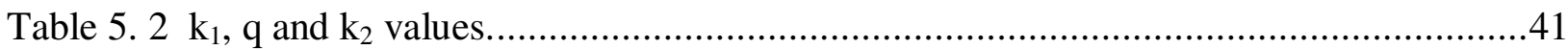




\section{Introduction}

Chalcopyrite $\left(\mathrm{CuFeS}_{2}\right)$ is the most abundant copper mineral and an important raw material source for copper production. Chalcopyrite is processed by both pyrometallurgical and hydrometallurgical processes to extract the copper metal. In the conventional pyrometallurgical smelting processes, chalcopyrite ore is concentrated by flotation to produce a high grade ore which is smelted in a furnace at high temperatures for recovery of copper. The Hydrometallurgical process involves crushing, leaching and other treatment steps such as solvent extraction and electrowinning usually at low temperatures. Currently, the majority of the tonnages of copper extraction from chalcopyrite are produced by pyrometallurgical processes.

Pyrometallurgical processes produce sulfur dioxide $\left(\mathrm{SO}_{2}\right)$ emissions which are then either converted to sulfuric acid or released to the atmosphere. However, the conversion of sulfur dioxide to sulfuric acid needs sufficient market demand for acid ${ }^{1}$. Venting of $\mathrm{SO}_{2}$ gases to the atmosphere causes acid rain; the United States government has tightened regulations on the emission of sulfur oxide gases under title IV of the 1990 Amendments of the Clean Air Act $(\mathrm{CAA})^{2}$ which demands complete $\mathrm{SO}_{2}$ capture.

To overcome the environmental and economic drawbacks of $\mathrm{SO}_{2}$ emissions, sulfuric acid market saturation and high operational costs of pyrometallurgical processes, constant efforts have been made to switch to hydrometallurgical processes. Hydrometallurgy offers alternatives

for producing copper from sulfide concentrates without producing $\mathrm{SO}_{2}$ and to recover most of the sulfur in the solid state ${ }^{3}$. Numerous processes have been developed in the past; still only few operate at full scale commercially. These processes used various reagents like ferric sulfate, 
ferric chloride, nitric oxide, ammonia and oxygen. Except for the process using oxygen and ammonia, all the other processes produce an elemental sulfur layer which inhibits the leaching rate. Research on the leaching of chalcopyrite with ferric sulfate or ferric chloride has been studied extensively in the past and a vast number of papers are available in the literature. The general problem with these processes is that the leaching kinetics of chalcopyrite is slow.

The purpose of this study is to investigate the leaching of chalcopyrite with a new reagent sodium hypochlorite to propose an economical and environmentally friendly industrial process for recovery of copper.

The objectives are:

1. To determine the effects of following parameters on the leaching rate/ conversion of chalcopyrite with sodium hypochlorite.

- Temperature,

- Initial $\mathrm{pH}$,

- Sodium hypochlorite concentration and

- Chalcopyrite dosage.

2. To establish a reaction kinetic model to explain the leaching rate of chalcopyrite with sodium hypochlorite solution. 


\section{Literature Review}

Copper has been in use for over five thousand years. With a sharp increase in the global copper production in the past 25 years (Figure 2.1), the availability of high grade copper ores is bound to decline $e^{4}$.

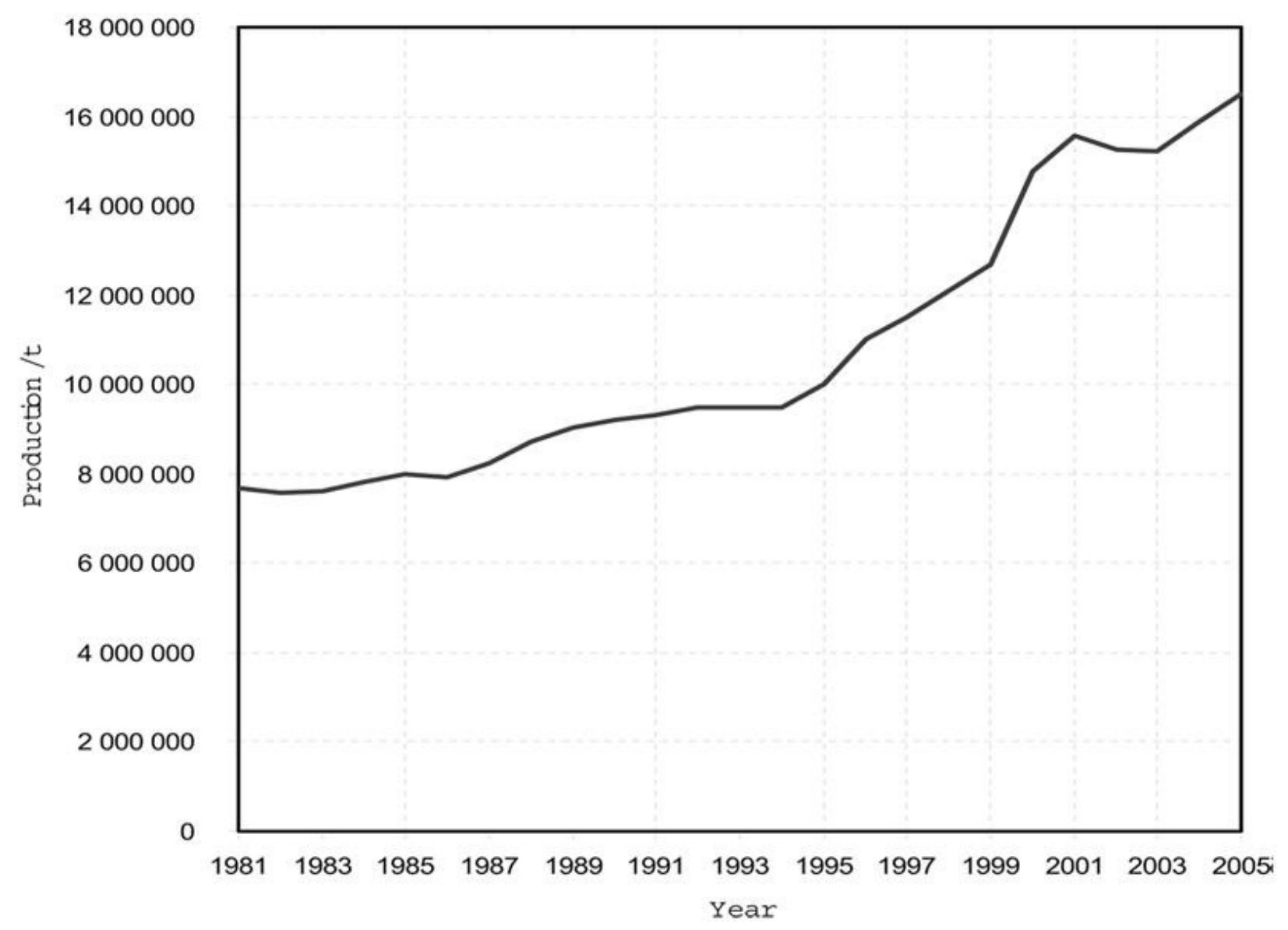

Figure 2. 1 World copper production since 1981-2005 (Data from Edeltein5 for the years 19812000 and from the International Copper Study Group6 for the years 2001- 2005).

According to the International Copper Study Group (ICSG), during the last decade world copper mineral production from mines increased by 30\% from 11.5 million metric tons in 1997 to 15 million metric tons in 2006. During this period the production of copper by the 
pyrometallurgical methods rose by $24 \%$ while by the hydrometallurgical processes rose by as high as $63 \%$. Furthermore, world copper mineral production from mines is expected to increase by $9 \%$ to 17.9 million metric tons by 2009 owing to mine developments and increased demand capacity of the copper metal. Therefore, it is considered essential to develop new alternative processes to the traditional pyrometallurgical processes one of which may be the hydrometallurgical process.

The hydrometallurgical copper processing generally consists of three fundamental operations $^{8}$ :

- $\quad$ Leaching of copper ore preferably with weak acid.

- Solvent extraction, in which the leach solution is mixed with an organic solvent, to recover copper from being acidic. The copper is then stripped from the organic solution with a strong acidic solution to obtain a highly concentrated copper rich solution.

- Electrowinning, where the copper rich solution is passed through a series of electrolytic cells to deposit copper on the cathodes.

There may arise, a question as to why first leaching in weak acid is followed by solvent extraction and again stripping using strong acid. When chalcopyrite is leached with sulfuric acid large amounts of iron enter into the solution which has to be precipitated before copper is recovered in the electrowinning process ${ }^{9}$. The presence of iron causes problems during the operation of the electrolytic cells in the electrowinning process, leading to a poor quality product and reduction of current efficiency. 


\subsection{Research Work}

Much research work has been conducted on leaching of chalcopyrite using various reagents such as sulfate, chloride, nitric acid, ammonia and biological systems. Some of them are discussed below.

\section{Sulfate Processes}

The leaching of chalcopyrite with acidic ferric sulfate solution has been studied by Munoz et al. $^{3}$ and Dutrizac ${ }^{10}$. The leaching of chalcopyrite in ferric sulfate system occurs by the reaction,

$$
\mathrm{CuFeS}_{2(\mathrm{~S})}+4 \mathrm{Fe}_{(\mathrm{aq})}^{3+} \rightarrow \mathrm{Cu}_{(\mathrm{aq})}^{2+}+5 \mathrm{Fe}_{(\mathrm{aq})}^{2+}+2 \mathrm{~S}_{(\mathrm{S})}^{0}
$$

Munoz et al. ${ }^{3}$ observed that the leaching of $12 \mu \mathrm{m}$ chalcopyrite particles in $0.25 \mathrm{M} \mathrm{Fe}_{2}\left(\mathrm{SO}_{4}\right)_{3}, 1$ $\mathrm{M} \mathrm{H}_{2} \mathrm{SO}_{4}$ at $90{ }^{\circ} \mathrm{C}$ took 100 hours to reach a conversion of $60 \%$. Similar results were also observed by Dutrizac ${ }^{10}$ when chalcopyrite was leached at $90^{\circ} \mathrm{C}$ in $0.2 \mathrm{M} \mathrm{Fe}\left(\mathrm{SO}_{4}\right)_{1.5}, 0.3 \mathrm{M}$ $\mathrm{H}_{2} \mathrm{SO}_{4}$. These authors suggested that the slow conversions are due to the formation of an elemental sulfur layer on the chalcopyrite surface which becomes a diffusion barrier and hence the rate is limited by the diffusion of ferric ion through the sulfur product layer.

\section{Chloride Processes}

The leaching of chalcopyrite with chloride solutions has gained importance over the last 30 years. The chloride processes have several distinct advantages over sulfate processes which include faster reaction kinetics of chalcopyrite leaching with chloride solutions than sulfate 
solutions, high solubility of copper and ferric ion, and the formation of porous elemental sulfur $\operatorname{product}^{11}$.

Leaching of chalcopyrite in chloride solutions was investigated by several investigators. Ferric chloride leaching of chalcopyrite was studied by Dutrizac ${ }^{10}$ and Palmer et al. ${ }^{12}$. Palmer et al. observed that their leaching rate followed the chemical reaction controlled kinetics model at 0.5 to $1 \mathrm{M}$ ferric chloride. Dutrizac observed that the ferric chloride system is 3 times more aggressive than the ferric sulfate system. These authors attributed that the reaction was under mixed electrochemical control and electron transfer occurring from iron chloride complexes.

Bonan et al. ${ }^{13}$ and Lundstrom et al. ${ }^{14}$ reported that the leaching of chalcopyrite by $\mathrm{CuCl}_{2}$ takes place as shown

$$
\mathrm{CuFeS}_{2}+3 \mathrm{Cu}^{2+}{ }_{(\mathrm{aq})} \rightarrow 4 \mathrm{Cu}_{(\mathrm{aq})}^{+}+\mathrm{Fe}^{2+}{ }_{(\mathrm{aq})}+2 \mathrm{~S}_{(\mathrm{s})}^{0}
$$

Bonan et al. ${ }^{13}$ studied the chalcopyrite leaching rates by $\mathrm{CuCl}_{2}$ in strong $\mathrm{NaCl}$ solutions in the temperature range from $75{ }^{\circ} \mathrm{C}$ to $104{ }^{\circ} \mathrm{C}$, chloride ion concentration of $4 \mathrm{~mol} / \mathrm{dm}^{3} \mathrm{NaCl}$ and the ratio of $\mathrm{Cu}^{2+} / \mathrm{Cu}^{+}$from 0.5 to 7 . It was observed that the leaching rates were much faster when the $\mathrm{Cu}^{2+} / \mathrm{Cu}^{+}$ratio was increased and also when the $\mathrm{Cl}^{-}$ion concentration was increased. It took 4 hours at $90{ }^{\circ} \mathrm{C}, 4 \mathrm{~mol} / \mathrm{dm}^{3} \mathrm{NaCl}$ and $\mathrm{Cu}^{2+} / \mathrm{Cu}^{+}$ratio of 1 to reach a conversion of $62 \%$. They found that the reaction was controlled by diffusion above $85^{\circ} \mathrm{C}$.

Lundstrom et al. ${ }^{14}$ studied the effect of temperature $\left(70{ }^{\circ} \mathrm{C}\right.$ to $\left.90{ }^{\circ} \mathrm{C}\right), \mathrm{pH}$ (1 to 3$)$ and the concentration of cupric ion $(0.09$ to $26.6 \mathrm{~g} / \mathrm{L})$ on the dissolution of chalcopyrite. The authors observed that for $\mathrm{pH}$ between 2 and 2.5, and with increasing cupric ion concentration above 9 $\mathrm{g} / \mathrm{L}$ the dissolution rates increased. They also proposed that with cupric ion concentrations above 
$9 \mathrm{~g} / \mathrm{L}$, at $\mathrm{pH} 2$ and at a temperature of $85{ }^{\circ} \mathrm{C}$, the rate is controlled by diffusion, but with lower cupric ion concentration, the reaction is under mixed or chemical control.

Lu et $a l .{ }^{15}$ have studied the effect of chloride ions on the leaching rate of chalcopyrite using oxygenated solutions. They found that when the chloride ion was absent, only $30 \%$ of copper was extracted, but with the presence of chloride $98 \%$ of the copper was extracted over a period of 9 hours. The authors also observed that chloride concentration above $0.5 \mathrm{M}$ does not increase the leaching rates. Similar results have been obtained by Palmer et al. ${ }^{12}$. They found that the rate increases until the chloride concentration reaches $0.5 \mathrm{M}$ but becomes independent of concentration for values greater than $1 \mathrm{M}$.

\subsection{Industrial Process}

Based on the electrochemical dissolution of chalcopyrite in the presence of ammonia, chloride and sulfate solutions, various processes have been developed but have not progressed beyond laboratory or pilot scale. Some of the processes are abandoned and few are currently operating at pilot scale.

Abandoned processes

1. Cymet process

2. Arbiter process

3. Clear process

Current processes

1. Outokumpu

2. Galvanox

3. Intec process 


\section{Cymet process:}

Cyprus metallurgical corporation developed the Cymet process at the pilot plant scale $^{16,17}$.

$$
\mathrm{CuFeS}_{2}+3 \mathrm{FeCl}_{3} \rightarrow \mathrm{CuCl}+4 \mathrm{FeCl}_{2}+2 \mathrm{~S}^{0}
$$

In this process chalcopyrite ore is partially leached according to the reaction 2.3 and the slurry is separated in a thickener and is introduced to a diaphragm electrolytic cell. The underflow goes to the anode side for further dissolution of unreacted chalcopyrite with hydrochloric acid.

$$
3 \mathrm{CuCl}+3 \mathrm{e}^{-} \rightarrow 3 \mathrm{Cu}^{0}+3 \mathrm{Cl}^{-}
$$

The overflow $(\mathrm{CuCl})$ goes to the cathode side for reduction to $\mathrm{Cu}^{0}$, according to reaction 2.4. The solution from the cathode of the copper electro-cell is purified and then goes to the iron electro cell for reduction of iron at the cathode and regeneration of $\mathrm{FeCl}_{3}$ at the anode. The overall reaction for the entire process showing the products as elemental copper, iron and sulfur is

$$
3 \mathrm{CuFeS}_{2}+9 \mathrm{e}^{-} \rightarrow 3 \mathrm{Cu}^{0}+3 \mathrm{Fe}^{0}+6 \mathrm{~S}^{0}
$$

Problems encountered with the Cymet process are the operation of electrolytic cells, coupled with poor quality product needing further refining. 


\section{Clear process:}

This process also uses ferric chloride as reagent similar to Cymet process. Leaching takes place in two stages. In the first stage chalcopyrite ore is oxidized to cupric chloride upon reaction with ferric chloride according to the reaction 2.6

$$
\mathrm{CuFeS}_{2}+4 \mathrm{FeCl}_{3} \rightarrow \mathrm{CuCl}_{2}+5 \mathrm{FeCl}_{2}+2 \mathrm{~S}^{0}
$$

In the second stage the cupric ions which are produced from the first stage are used as an oxidizing reagent in the second stage as shown

$$
\mathrm{CuFeS}_{2}+3 \mathrm{CuCl}_{2} \rightarrow 4 \mathrm{CuCl}+\mathrm{FeCl}_{2}+2 \mathrm{~S}^{0}
$$

The cuprous chloride thus obtained is mixed with $\mathrm{NaCl}$ to form $\mathrm{CuCl}_{2}{ }^{-}$anion and electrolyzed in a diaphragm cell to produce copper. The purity of the copper powder produced was poor due to the lack of leach solution purification ${ }^{18}$.

\section{Arbiter/ Ammonia process:}

This process was developed in 1970 by Arbiter. The process is based on leaching of chalcopyrite concentrates with ammonia at $75-80{ }^{\circ} \mathrm{C}$ in presence of oxygen to form copper ammine sulfate and iron hydroxide ${ }^{19}$.

$2 \mathrm{CuFeS}_{2}+8.5 \mathrm{O}_{2}+12 \mathrm{NH}_{3}+2 \mathrm{H}_{2} \mathrm{O} \rightarrow 2 \mathrm{Cu}\left(\mathrm{NH}_{3}\right)_{4} \mathrm{SO}_{4}+2\left(\mathrm{NH}_{3}\right)_{4} \mathrm{SO}_{4}+\mathrm{Fe}_{2} \mathrm{O}_{3}$

After filtering the solids, copper from the pregnant leach solution is recovered by solvent extraction, stripped by sulfuric acid, and then copper is removed by electrowinning. The ammonia is recovered by treating the ammonium sulfate with calcium oxide and steam to produce calcium sulfate (gypsum). Gypsum is not a desirable waste and has a limited market. 


$$
(\mathrm{NH} 4)_{2} \mathrm{SO}_{4}+\mathrm{Ca}(\mathrm{OH})_{2} \rightarrow 2 \mathrm{NH}_{3}+\mathrm{CaSO}_{4} \cdot 2 \mathrm{H}_{2} \mathrm{O}
$$

This ammonia recovery step as well as the residue washings proved to be technically difficult and economically unsound and was the main reason for the shut down.

Most recently, novel processes in chloride media promoted by Intec, Galvanox and Outokumpu addressed the problem of purity and developed new processes.

\section{Outokumpu HydroCopper process:}

In this process, copper concentrate is leached into a strong sodium chloride solution containing $\mathrm{CuCl}_{2}$, in agitated reactors at a temperature $85-90{ }^{\circ} \mathrm{C}$. Air is blown to precipitate iron as the oxide or hydroxide at $\mathrm{pH}$ of 1.2- 2.5. Chalcopyrite is leached in the chloride solution with the help of $\mathrm{Cu}^{2+}$ according to the reaction

$$
\mathrm{CuFeS}_{2}+3 \mathrm{Cu}^{2+} \rightarrow 4 \mathrm{Cu}^{+}+\mathrm{Fe}^{2+}+2 \mathrm{~S}
$$

Ferrous iron is oxidized as

$$
\mathrm{CuFeS}_{2}+\mathrm{Cu}^{2+}+0.75 \mathrm{O}_{2} \rightarrow 2 \mathrm{Cu}^{+}+0.5 \mathrm{Fe}_{2} \mathrm{O}_{3}+2 \mathrm{~S}^{0}
$$

The pregnant leach solution contains $\mathrm{Cu}^{+}, \mathrm{Cu}^{2+}$ and other metals which are purified. Copper is recovered from the purified leach solution by precipitating cuprous oxide. The pure, solid copper is melted and cast directly into shapes. The main key of this process is the regeneration of reactants using chlor-alkali electrolysis technology from the spent brine: caustic soda, chlorine for oxidation of the leach solution; and hydrogen to reduce the cuprous oxide to copper ${ }^{20}$.

\section{Galvanox process:}

This process is based on leaching by making a galvanic couple between the more "electrochemically noble" pyrite, and chalcopyrite thus enhancing the leaching rate under 
atmospheric, medium temperature $\left(80^{\circ} \mathrm{C}\right)$ conditions in acidic iron sulfate solution. The presence of pyrites provides the catalytic effect for the leaching of chalcopyrite without passivation $^{21}$. 


\section{Theory}

\section{Hypochlorous acid and Hypochlorite leaching}

The solution chemistry of chlorine is characterized by the following equilibria:

$$
\begin{array}{ll}
\mathrm{HClO}=\mathrm{H}^{+}+\mathrm{OCl}^{-} & \mathrm{K}=3.3 \times 10^{-8} \\
\mathrm{HClO}+\mathrm{Cl}^{-}+\mathrm{H}^{+}=\mathrm{Cl}_{2(\mathrm{aq})}+\mathrm{H}_{2} \mathrm{O} & \mathrm{K}=2.3 \times 10^{3} \\
\mathrm{Cl}_{2(\mathrm{~g})}=\mathrm{Cl}_{2(\mathrm{aq})} & \mathrm{K}=0.02 \\
\mathrm{Cl}_{2(\mathrm{aq})}+\mathrm{Cl}^{-}=\mathrm{Cl}_{3}^{-} & \mathrm{K}=0.2
\end{array}
$$

The above equilibrium constants are those at $25^{\circ} \mathrm{C}$ and obtained from Reference 22.

Hypochlorite $\left(\mathrm{OCl}^{-}\right)$is predominant at high solution $\mathrm{pH}$ such as above 10. As $\mathrm{pH}$ decreases, hypochlorous acid $(\mathrm{HClO})$ becomes predominant. The $\mathrm{pH}$ where the concentrations of the two species are the same falls in at 7.5. As the $\mathrm{pH}$ further decreases, hypochlorous acid turns to aqueous chlorine which will ultimately escape from the solution as gaseous chlorine.

Cho studied the leaching of chalcopyrite with hypochlorous acid ( $\mathrm{HClO})$, the predominant chlorine derivative in concentration at acidic conditions $(\mathrm{pH} \mathrm{3-7})^{22}$. It was found that the leaching of $-65+100$ mesh sized particles with 0.23 molar concentration of hypochlorous acid at room temperature achieved about $90 \%$ conversion in 1 hour at room temperature. The $\mathrm{pH}$ was maintained at 4 by adding $\mathrm{NaOH}$ solution.

In the present study chalcopyrite is leached with sodium hypochlorite $(\mathrm{NaOCl})$, the predominant chlorine derivative in concentration at high $\mathrm{pH}$ levels. The leaching takes place in 
two separate stages. In the first stage, the mineral is converted to cupric oxide with hypochlorite which is subsequently dissolved in an acid solution in the second stage.

The leaching of chalcopyrite with hypochlorite may take place by electrochemical reaction. The anodic reaction may be written as

$\mathrm{CuFeS}_{2}+12 \mathrm{H}_{2} \mathrm{O}=\mathrm{CuO}_{(\mathrm{s})}+\mathrm{Fe}(\mathrm{OH})_{3(\mathrm{~s})}+2 \mathrm{SO}_{4}{ }^{2-}+21 \mathrm{H}^{+}+17 \mathrm{e} \quad \mathrm{E}^{\mathrm{o}}=0.42 \mathrm{eV}$

And the cathodic reaction is

$\mathrm{OCl}^{-}+2 \mathrm{H}^{+}+2 \mathrm{e}=\mathrm{Cl}^{-}+\mathrm{H}_{2} \mathrm{O} \quad \mathrm{E}^{\mathrm{o}}=1.71 \mathrm{eV}$

The $\mathrm{E}^{\mathrm{o}}$ value of reaction 3.5 is for the reduction reaction. The difference in $\mathrm{E}^{\mathrm{o}}$ between the anodic and cathodic reactions is large, suggesting that the overall reaction will be thermodynamically feasible under normal conditions. The overall reaction will be written as

$\mathrm{CuFeS}_{2}+3.5 \mathrm{H}_{2} \mathrm{O}+8.5 \mathrm{OCl}^{-}=\mathrm{CuO}_{(\mathrm{s})}+\mathrm{Fe}(\mathrm{OH})_{3(\mathrm{~s})}+2 \mathrm{SO}_{4}{ }^{2-}+4 \mathrm{H}^{+}+8.5 \mathrm{Cl}^{-}$

It is can be seen that 8.5 moles of hypochlorite are required to leach one mole of chalcopyrite or the stoichiometric ratio of hypochlorite is 8.5. Since the first stage leaching is carried at high pHs, the converted $\mathrm{CuO}$ may be dissolved to oxy-anion, $\mathrm{CuO}_{2}{ }^{2-}$. The reaction is written as

$\mathrm{CuO}+\mathrm{H}_{2} \mathrm{O}=\mathrm{CuO}_{2}{ }^{2-}+2 \mathrm{H}^{+} \quad \mathrm{K}\left(25^{\circ} \mathrm{C}\right)=7.72 \times 10^{-33}$

It is seen from the equilibrium constant of reaction 3.8 that the oxy-anion concentration is essentially zero unless the $\mathrm{pH}$ becomes very high (e.g., 13). The oxy-anion concentration in the ppm range was observed in the first stage leaching in this study. 
In the second stage, $\mathrm{CuO}$ is leached with sulfuric acid. The leaching reaction is written as

$\mathrm{CuO}+2 \mathrm{H}^{+}=\mathrm{Cu}^{2+}+\mathrm{H}_{2} \mathrm{O}$

In the study, chalcopyrite ore is partially leached with sodium hypochlorite in the first stage in which the $\mathrm{Cu}$ is converted to $\mathrm{CuO}_{(\mathrm{s})}, \mathrm{Fe}$ is converted to $\mathrm{Fe}(\mathrm{OH})_{3(\mathrm{~s})}$ and sulfur is liberated into the solution which is removed as sulfate. The slurry is separated by filtration. In the second stage the copper oxide is leached with sulfuric acid to cupric sulfate.

The advantage of using sodium hypochlorite is, in the second stage the leaching of copper oxide at a constant $\mathrm{pH}$ with sulfuric acid (e.g., $\mathrm{pH}>3$ ) may prevent the dissolution of iron content, which will benefit the subsequent processes of solvent extraction and electrowinning. 


\section{Experimental Methods}

\subsection{Materials}

Chalcopyrite samples purchased from Wards Mineral (Rochester, NY) were used in this study. Lumps of samples were crushed and screened to give a fraction of 200 x 270 mesh size. This sized fraction was further concentrated by a conventional flotation technique using amyl xanthate as a collector and MIBC (methyl isobutyl carbinol) as a frother. Chemical analyses were conducted by dissolving the sized fraction with aqua-regia solution and analyzing the leach solution with an atomic absorption unit (Perkin Elmer model) in order to determine the purity of chalcopyrite. The results showed that the average composition was $88.62 \% \mathrm{CuFeS}_{2}$ and $4.7 \%$ $\mathrm{ZnS}$.

Hypochlorite solutions used for the leaching experiments were prepared by diluting the hypochlorite stock solution, which was purchased from a chemical supplier (VWR). The hypochlorite concentration was about 1.8 molar. As soon as it was received, extra $\mathrm{NaOH}$ pellets of $7 \mathrm{~g} /$ liter were added and stored in a refrigerator to minimize the loss due to evaporation.

\subsection{Leaching experiments with hypochlorite}

The leaching experiments with chalcopyrite were conducted in a one-liter reactor placed in a constant-temperature paraffin-oil bath. Figure 4.1 shows the schematic diagram of the experimental setup. The reactor has four necks. The central neck is equipped with a stirrer connected to a motor running at $500 \mathrm{rpm}$. One of the side necks is fitted with a reflux condenser which is used to prevent excessive evaporation at high temperatures. The next one is equipped with a thermometer which is used to measure the temperature of the solution. And the last one is 
used for charging the mineral sample, and pipetting out solution for analysis of chlorine and sulfate concentrations.

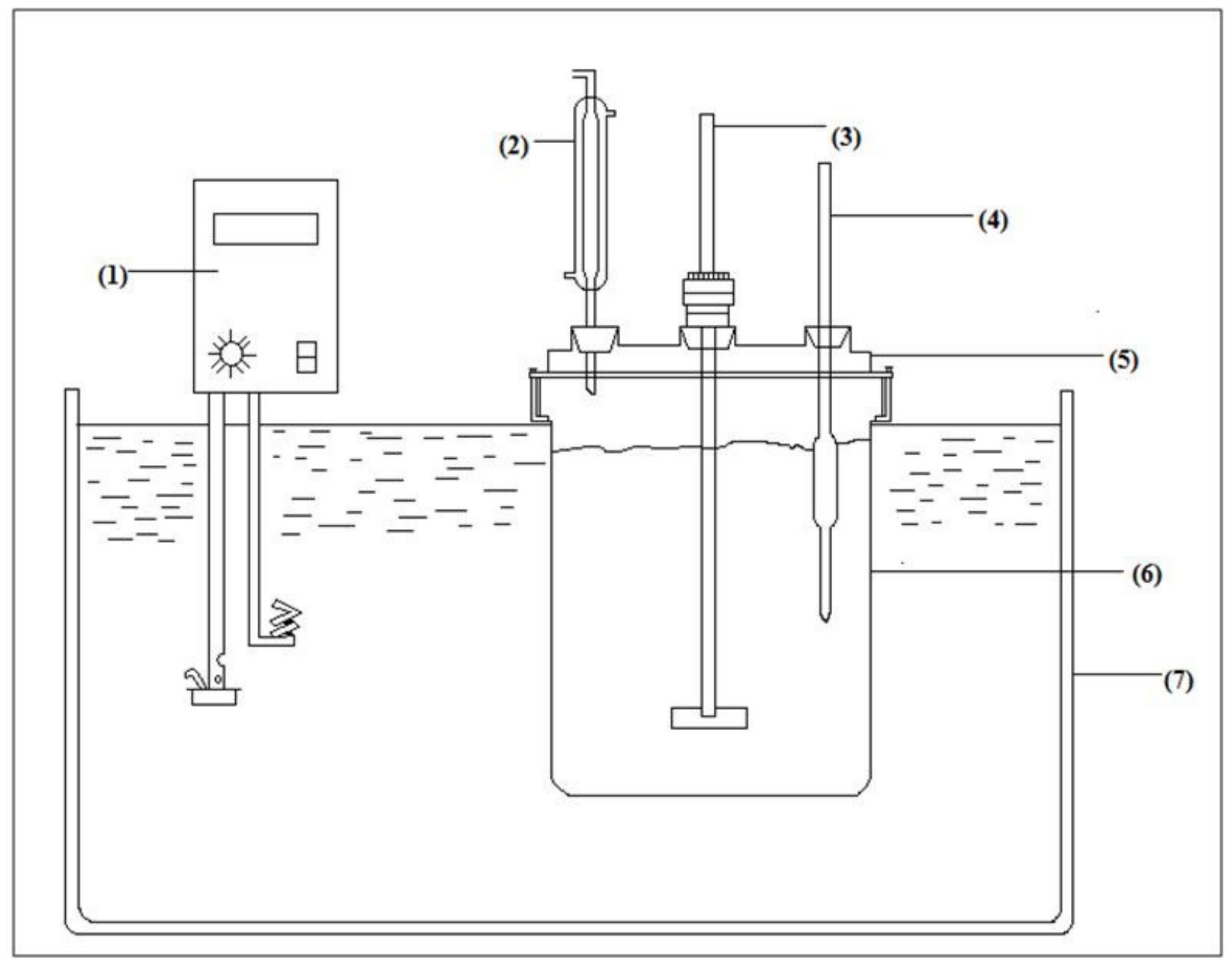

Figure 4. 1 Schematic diagram of leaching apparatus.

1. Temperature controller

2. Reflux condenser

3. Stirrer

4. Sampling pipette

5. Glass cover

6. Glass reaction vessel

7. Paraffin oil bath 
Five hundred milliliters of hypochlorite solution at the desired concentration were charged into the reactor. When the leach solution reached the desired temperature, a 2-5 ml solution was withdrawn from the reactor and analyzed for hypochlorite. It was found that the original concentration did not decrease during the heating period for all the experiments conducted in this study. Then a predetermined amount of chalcopyrite sample was added to the reactor. The leaching continued for up to 1 hour. Twenty-milliliter liquid samples were withdrawn from the reactor at 15, 30 and 60 minutes. Shortly before each sample was taken (about 10 seconds), the stirring was momentarily stopped in order to minimize the solid content in the sample. Treatment of the samples will be described later under section 4.4. After leaching, the chalcopyrite slurry was vacuum filtered and washed three times, each time with a 150-200 ml 0.5 molar $\mathrm{NaOH}$ solution to remove remnant hypochlorite. Then the solid was similarly washed with deionized water three times to remove sodium hydroxide. Finally the filtered and washed chalcopyrite was dried under infrared light, and was used for acid leaching in the second stage.

\subsection{Leaching Experiments with Sulfuric Acid}

The filtered and dried chalcopyrite from the first stage was repulped in $500 \mathrm{ml}$ of 1 normal sulfuric acid. In this second stage, the converted cupric oxide was leached with the sulfuric acid. The same reactor was used. The temperature was room temperature. The stirring speed was 500 rpm. The leaching continued for 90 minutes. These conditions were found to be rigorous enough to completely leach cupric oxide through preliminary experiments. At the end of the leaching, the slurry was vacuum filtered and the filtrate was diluted properly before analyzing for copper by atomic absorption. 


\subsection{Analyses}

The chlorine concentration of the hypochlorite solution was analyzed according to American Society for Testing and Materials (ASTM) method D2022-64. Solid potassium iodide was added to the chlorine-containing solution and dissolved. The solution was acidified by adding concentrated acetic acid. The aqueous chlorine oxidizes the iodide to iodine, which was titrated by sodium thiosulfate solution, using starch as an indicator.

In the preliminary study, three separate experiments were conducted to complete one leaching curve during the first stage at three different times such as 1,2 and 3 hours. The largest disadvantage of this method was that since different solid samples were used each time, the leaching curve might produce some errors that could not be specified. Thus, a new method was designed in this study. Approximately $20 \mathrm{ml}$ of solution was withdrawn from the reactor using a 20-ml pipette each time at 15, 30 and 60 minutes, and filtered using a Whatman No.42 filter paper. A 10-ml solution was pipetted from the filtrate and used to analyze the sulfate content; a 2-5-ml solution was used to analyze the hypochlorite concentration; and the rest was returned to the reactor. The conversion of chalcopyrite during the first stage at each 15 and 30 minutes was determined using the concentration of sulfate ion and the molar ratio of sulfate to cupric at 60 minutes. This ratio at 60 minutes was determined later by the cupric concentration from the second stage leaching. This method is based on the assumption that the molar ratio of sulfate to cupric is maintained throughout the first stage, which is reflected on reaction 2.18 . The average ratio was observed to be about 2.5. Since the theoretical ratio is 2 as shown in reaction 2.18 , the higher value may be due to other sulfate sources such as $\mathrm{ZnS}$. However, this experimental ratio of 2.5 may verify that the sulfur product from the leaching of chalcopyrite is sulfate rather than elemental sulfur. 
Sulfate was analyzed by ASTM D 3177-84 which is designed to analyze total sulfur in coal. This method is based on precipitation of sulfate as barium sulfate by adding barium chloride solution, followed filtration and ignition. The $\mathrm{pH}$ of the filtrate before adding barium chloride was adjusted to 2.2 by using a $\mathrm{pH}$ meter instead of using methyl orange because it was decolorized by hypochlorite.

Only once, chloride ion in the hypochlorite stock solution was analyzed using ASTM D 2361-85 which is designed to analyze chlorine in coal. This method is based on the back titration of silver ion after precipitating chloride ion with excessive silver nitrate with potassium thiocyanate using ferric ammonium sulfate as an indicator.

\section{Copper Analysis by Atomic Absorption}

Atomic absorption spectrophotometry is a standard laboratory technique for solution analysis in which the concentration of an element in the solution is determined by measuring the absorption of radiation in the atomic vapor produced from the sample at a wavelength that is specific and characteristic of the element. According to Beer's law the absorbance should be linear function of concentration. At high concentrations of absorbing species deviation from linearity is observed. Therefore, strong solution should be diluted so that the concentration is in linear working range. The linear working range of copper is up to $5 \mathrm{ppm}$ (mg/ liter). $100 \mathrm{ml}$ of standard copper solutions of 1, 2, 3, 4 and 5 ppm are prepared by diluting 1000 ppm copper stock solution. 


\section{Results}

\subsection{XRD patterns:}

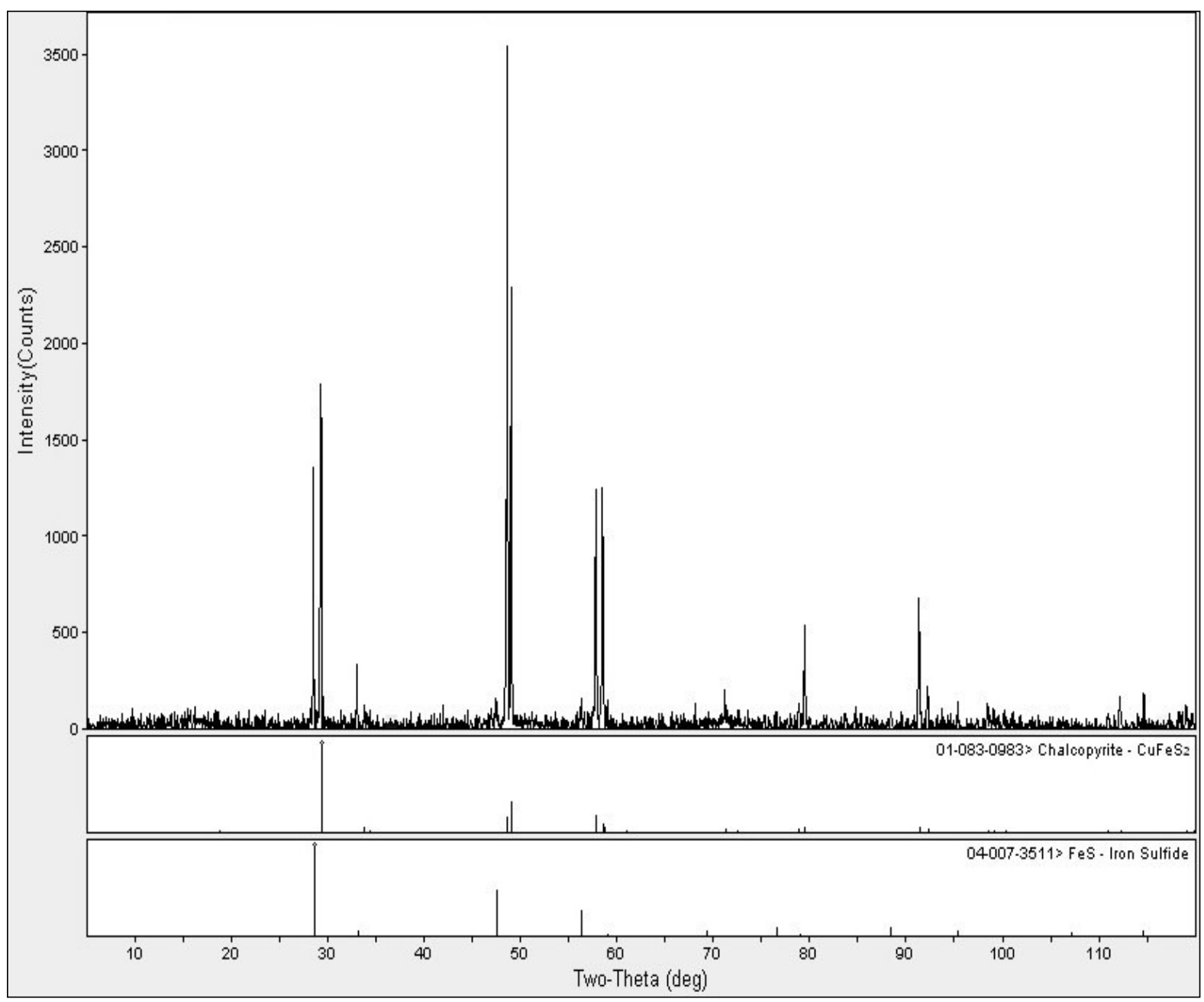

Figure 5.1 X-Ray diffraction spectra of the unleached chalcopyrite mineral sample.

The XRD pattern for the unleached chalcopyrite mineral sample is shown in Figure 5.1. As seen in Figure 5.1, the chalcopyrite $\left(\mathrm{CuFeS}_{2}\right)$ is characterized by two-theta peak values of 29.4, 49.1 and 57.9 degrees. Figure 5.2 shows the XRD patterns for the leached/converted chalcopyrite sample. The leaching experiment conducted at $55^{\circ} \mathrm{C}, 0.5$ molar of hypochlorite, $\mathrm{pH}$ 
13.15 and 1 hour. The leached sample washed with sodium hydroxide solution and deionized water, as described previously. The leaching conversion found to be about $67 \%$.

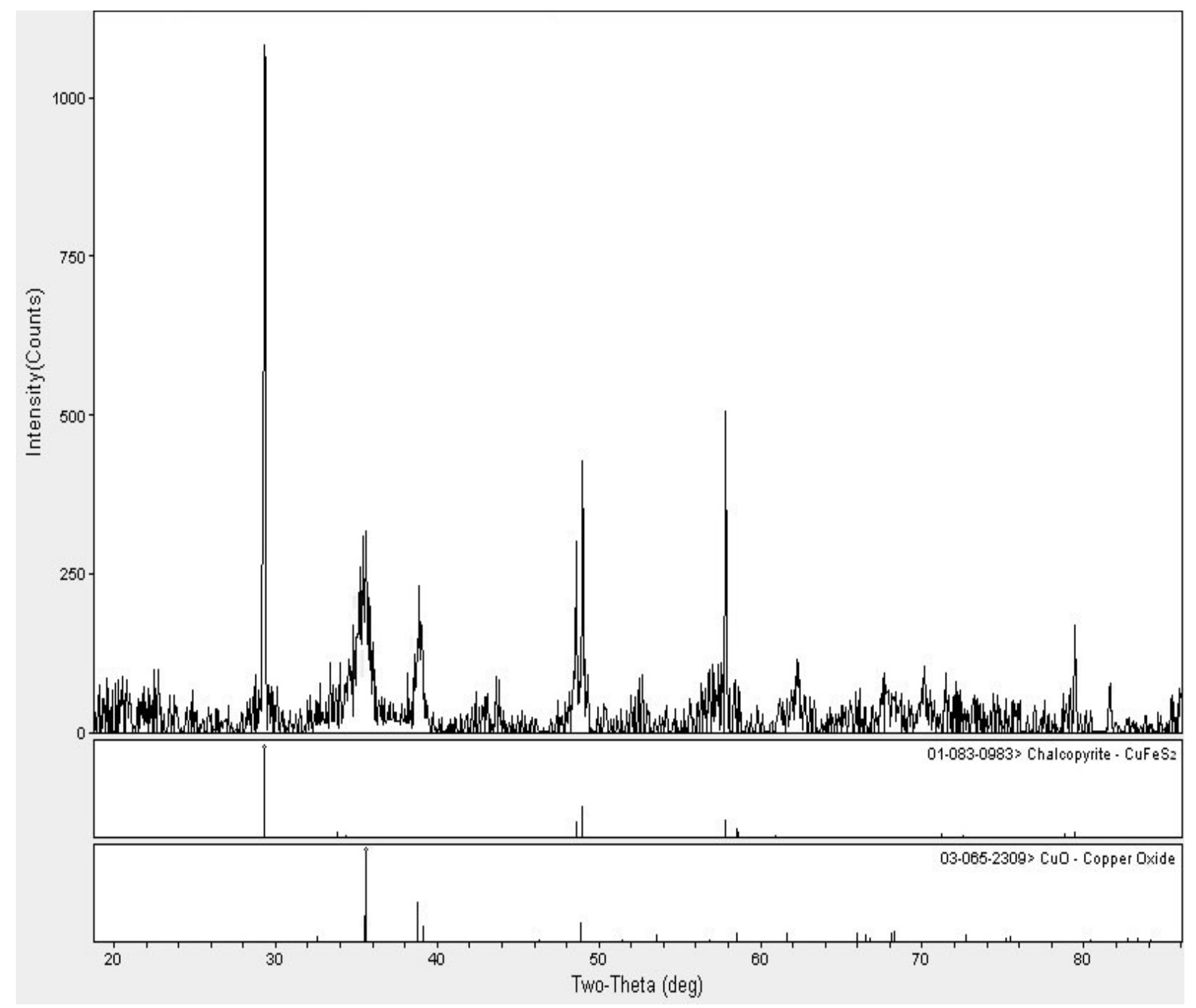

Figure 5.2 X-Ray diffraction spectra of the leached chalcopyrite sample after first stage of leaching $\left(55^{\circ} \mathrm{C}, 0.5\right.$ molar $\mathrm{OCl}-$, 3grams chalcopyrite, initial $\left.\mathrm{pH} 13.15\right)$.

The two-theta peak values of 29.4, 49.1 and 57.9 are maintained as shown in Figure 5.2, representing the unleached chalcopyrite. As demonstrated in figure 5.2, the two two-theta peaks at 35.6 and 38.8 degrees coincided with $\mathrm{CuO}$ pattern, verifying that the leach product is $\mathrm{CuO}$. 


\subsection{Effect of stirring speed:}

Figure 5.3 shows the results of a series of experiments conducted to determine the effect of stirring speed ${ }^{24}$. Experimental conditions were temperature at $85^{\circ} \mathrm{C}, \mathrm{pH} 13$ and hypochlorite concentration 0.5 molar. The results reveal that the leaching rate increases as the stirring speed increases from 265 to $500 \mathrm{rpm}$. Nonetheless, the stirring speed of 500 is used for all the subsequent experiments.

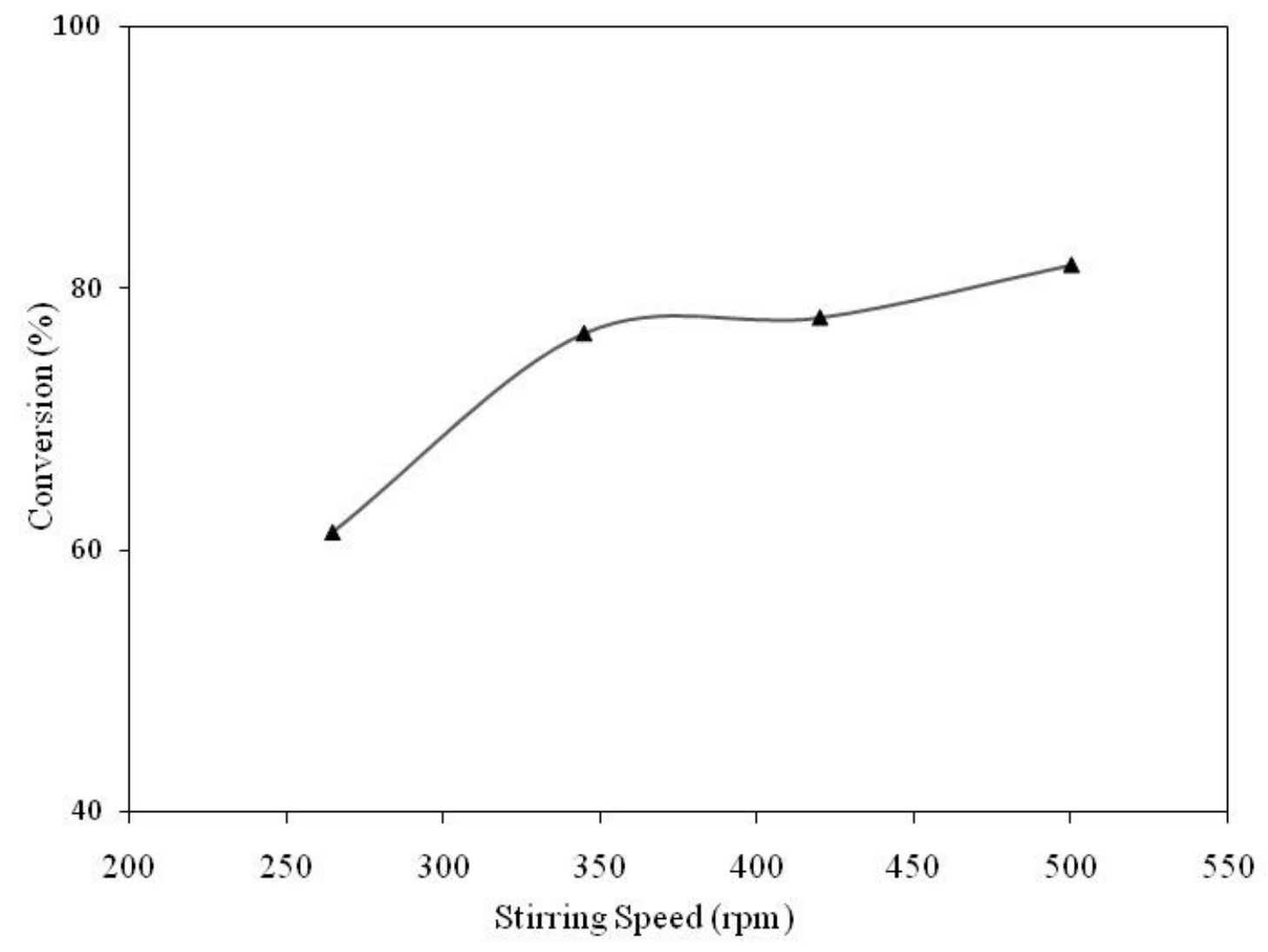

Figure 5.3 Effect of stirring speed on leaching conversion of chalcopyrite $\left(85^{\circ} \mathrm{C}\right.$, hypochlorite concentration $0.5 \mathrm{M}, \mathrm{pH}-13.00$. 


\subsection{Effect of pH:}

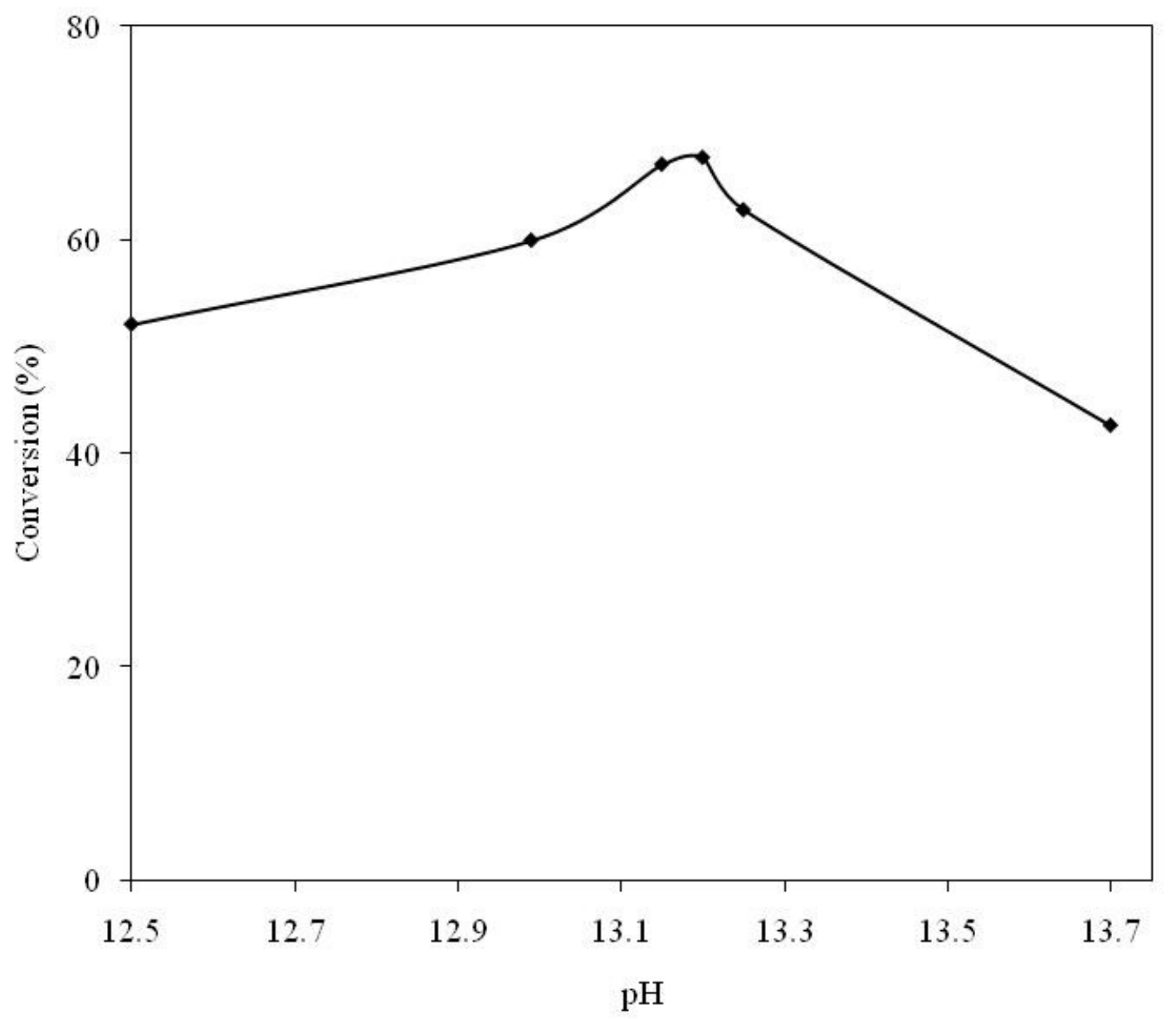

Figure 5.4 Effect of initial $\mathrm{pH}$ on chalcopyrite leaching conversion $\left(55^{\circ} \mathrm{C}, 0.5\right.$ molar $\mathrm{OCl}-, 3$ grams chalcopyrite, 60 minutes reaction time).

Figure 5.4 shows the effect of initial $\mathrm{pH}$ on leaching conversion of chalcopyrite to cupric oxide at 1 hour during the first stage of leaching. The leaching conversion is defined as the fraction of chalcopyrite leached into cupric oxide. The initial $\mathrm{pH}$ varied from 12.5 to 13.7 , at a temperature of $55^{\circ} \mathrm{C}$, hypochlorite concentration of 0.5 molar, with chalcopyrite dosage of 3 grams in $500 \mathrm{ml}$. It is observed from the experimental results that the leaching conversion shows 
a maximum at $\mathrm{pH}$ 13.15-13.20. Figure 5.5, shows the depletion of hypochlorite concentration as a function of time during the first stage leaching for the same experiments as for Figure 5.4.

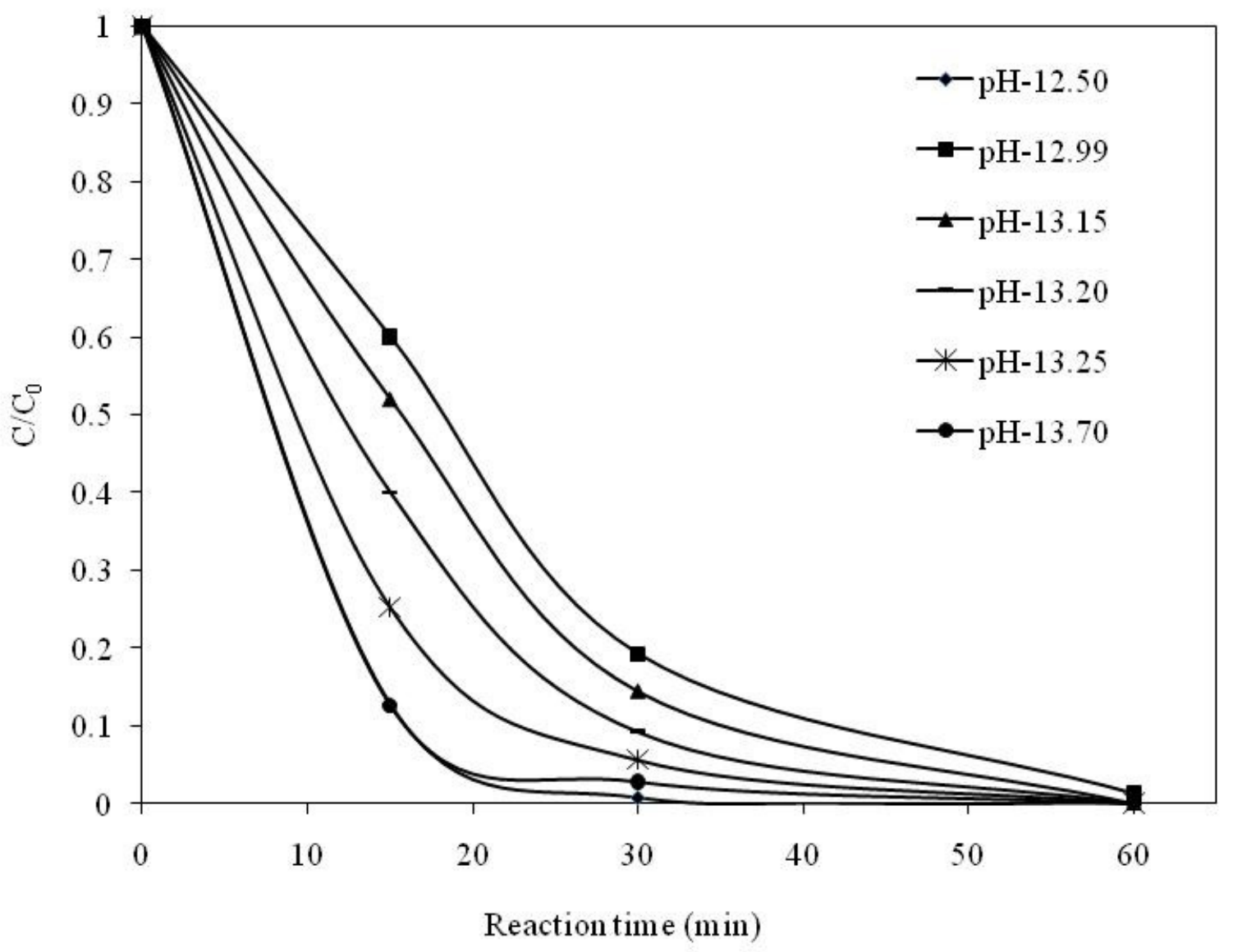

Figure 5.5 Effect of $\mathrm{pH}$ on hypochlorite depletion $\left(55^{\circ} \mathrm{C}, 0.5\right.$ molar $\mathrm{OCl}-, 3$ grams chalcopyrite).

It can be seen in Figure 5.5 that the $\mathrm{pH}$ values yielding the maximum conversion coincide

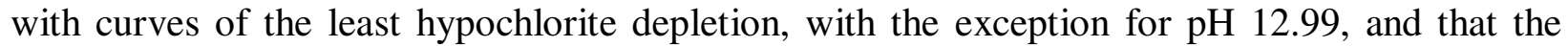
lower conversions at both $\mathrm{pH}$ ends in Figure 5.4 coincide with the curves of higher reagent depletion. 
Table 5. 1 Effect of $\mathrm{pH}$ on Leaching of Chalcopyrite in First Stage $\left(55{ }^{\circ} \mathrm{C}, 0.5\right.$ molar $\mathrm{OCl}^{-}$, 3 grams chalcopyrite).

\begin{tabular}{|c|c|c|c|c|c|c|}
\hline $\begin{array}{c}\text { NaOH added } \\
\text { (grams) }\end{array}$ & 0 & 2 & 4 & 8 & 12 & 20 \\
\hline Initial pH & 12.5 & 12.99 & 13.15 & 13.20 & 13.25 & 13.70 \\
\hline Final pH & 11.9 & 12.55 & 12.88 & 12.91 & 12.99 & 13.2 \\
\hline $\begin{array}{c}\text { Concentration of } \\
\mathrm{Cu}^{++}(\mathrm{ppm}) \text { in the } \\
\text { first stage }\end{array}$ & 0.19 & 0.21 & 0.3 & 0.77 & 3.24 & 26.54 \\
\hline $\begin{array}{c}\text { Hypochlorite } \\
\text { consumption* }\end{array}$ & 33.09 & 28.15 & 25.23 & 25.18 & 27.30 & 40.45 \\
\hline
\end{tabular}

*Hypochlorite consumption is defined as the number of moles of hypochlorite consumed to the number of moles of chalcopyrite leached.

Table 5.1 gives numerical data for this effect. The soluble cupric concentration (the cupric oxy-anion) increases as $\mathrm{pH}$ increases and reaches $26.54 \mathrm{ppm}$ at $\mathrm{pH} 13.7$. Table 5.1 also gives hypochlorite consumption ratio at various $\mathrm{pHs}$. This is calculated by dividing the number of moles of hypochlorite depleted by the number of moles of chalcopyrite leached. The ratio shows the minimum value of 25.18 at $\mathrm{pH} 13.2$ which yields the maximum leaching conversion.

A question arises as to the mechanism(s) which leads to the pattern of hypochlorite depletion as shown in Figure 5.5. The fast depletion at $\mathrm{pH} 12.5$ is because hypochlorite is not stable at lower pHs. However, this is not the case for high hypochlorite depletion at $\mathrm{pH}$ 13.7. It is assumed first that the fast depletion at $\mathrm{pH} 13.7$ is due to the catalysis by cupric oxy-anion. However, this could not be proven due to the inability of hypochlorite depletion from an experiment where 0.5 molar of hypochlorite in the presence of $0.5 \mathrm{ppm}$ of cupric oxy-anion at $55^{\circ} \mathrm{C}$ and $\mathrm{pH} 13.7$ was allowed to react up to 1 hour without the solid sample. 
It is particularly interesting to note the effect of initial $\mathrm{pH}$ at 11.9. This $\mathrm{pH}$ is adjusted by adding $5 \mathrm{ml} 10 \%$ sulfuric acid in $500 \mathrm{ml}$ of 0.5 molar of hypochlorite. The rest of the conditions were the same as for Figure 5. The results showed that the final $\mathrm{pH}$ decreased to 8.3 and the cupric concentration reached $1161 \mathrm{ppm}(63.3 \%$ conversion equivalent) and the conversion to solid cupric oxide was $18.4 \%$. It may be surmised that at the final $\mathrm{pH}$ of 8.3 a significant amount of hypochlorous acid $(\mathrm{HClO})$ is produced and able to leach chalcopyrite to cupric-chloride complexes.

If the hypochlorite stock solution is prepared by dissolving chlorine gas into sodium hydroxide solution, chloride concentration will be the same as that of hypochlorite. In this experiment cupric ion could be in solution at this $\mathrm{pH}$ because it could form complexes with chloride ions. Chloride ion was analyzed in the hypochlorite stock solution. From the result it is found that the chloride concentration (1.63 molar) was $9.4 \%$ lower than that of hypochlorite (1.8 molar). This disparity may be due to the loss of both species as gaseous chlorine during the acidification of the solution. It is concluded then from this experiment that the leaching at the initial $\mathrm{pH}$ of 11.9 gives completely different mechanism from experiments conducted at initial $\mathrm{pH}$ of 12.5 or larger. 


\subsection{Effect of temperature:}

The effect of temperature on leaching conversion of chalcopyrite examined by varying the temperatures from $35^{\circ} \mathrm{C}$ to $75^{\circ} \mathrm{C}$, with 3 grams of chalcopyrite and at 0.5 molar of hypochlorite. Figure 5.6 shows the results of the experiments.

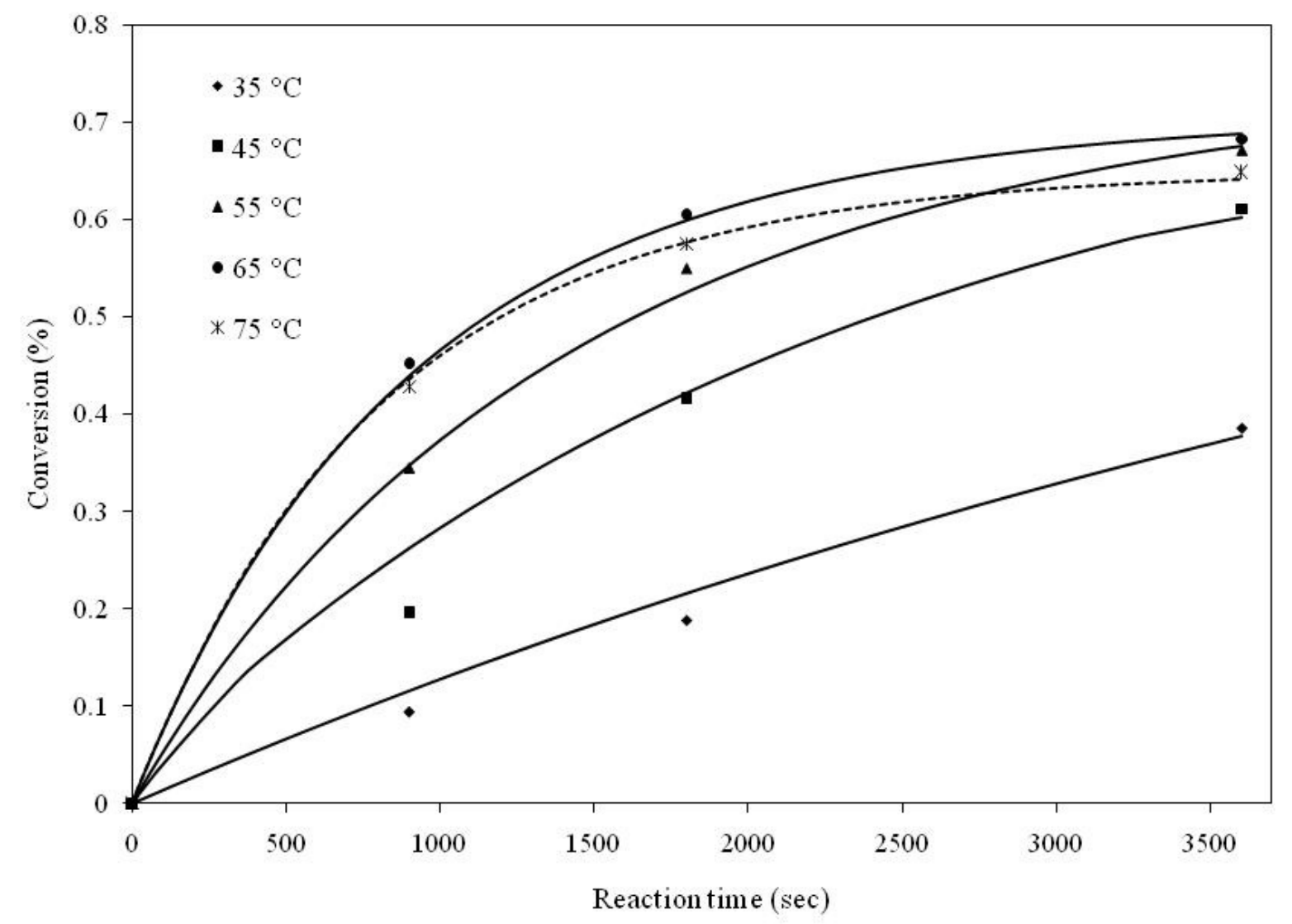

Figure 5.6 Effect of temperature on chalcopyrite leaching conversion (0.5 molar OCl-, 3 grams chalcopyrite, $\mathrm{pH} 13.15)$.

The leaching conversion increased with increasing temperature up to $65^{\circ} \mathrm{C}$ not much upon further increasing the temperature to $75^{\circ} \mathrm{C}$. Experiments above $75^{\circ} \mathrm{C}$ could have been performed to verify the trend; however, difficulty existed in analyzing hypochlorite concentration because of its fast depletion rate. The cupric oxy-anion concentration was also 
detected during this series, and was found to be $2.14 \mathrm{ppm}$ at $35^{\circ} \mathrm{C}, 0.3 \mathrm{ppm}$ at $55^{\circ} \mathrm{C}$, and 0.23 ppm at $75^{\circ} \mathrm{C}$. From this trend, it can be verified on the basis of Le Chatelier's principle that reaction 3.8 is an exothermic reaction.

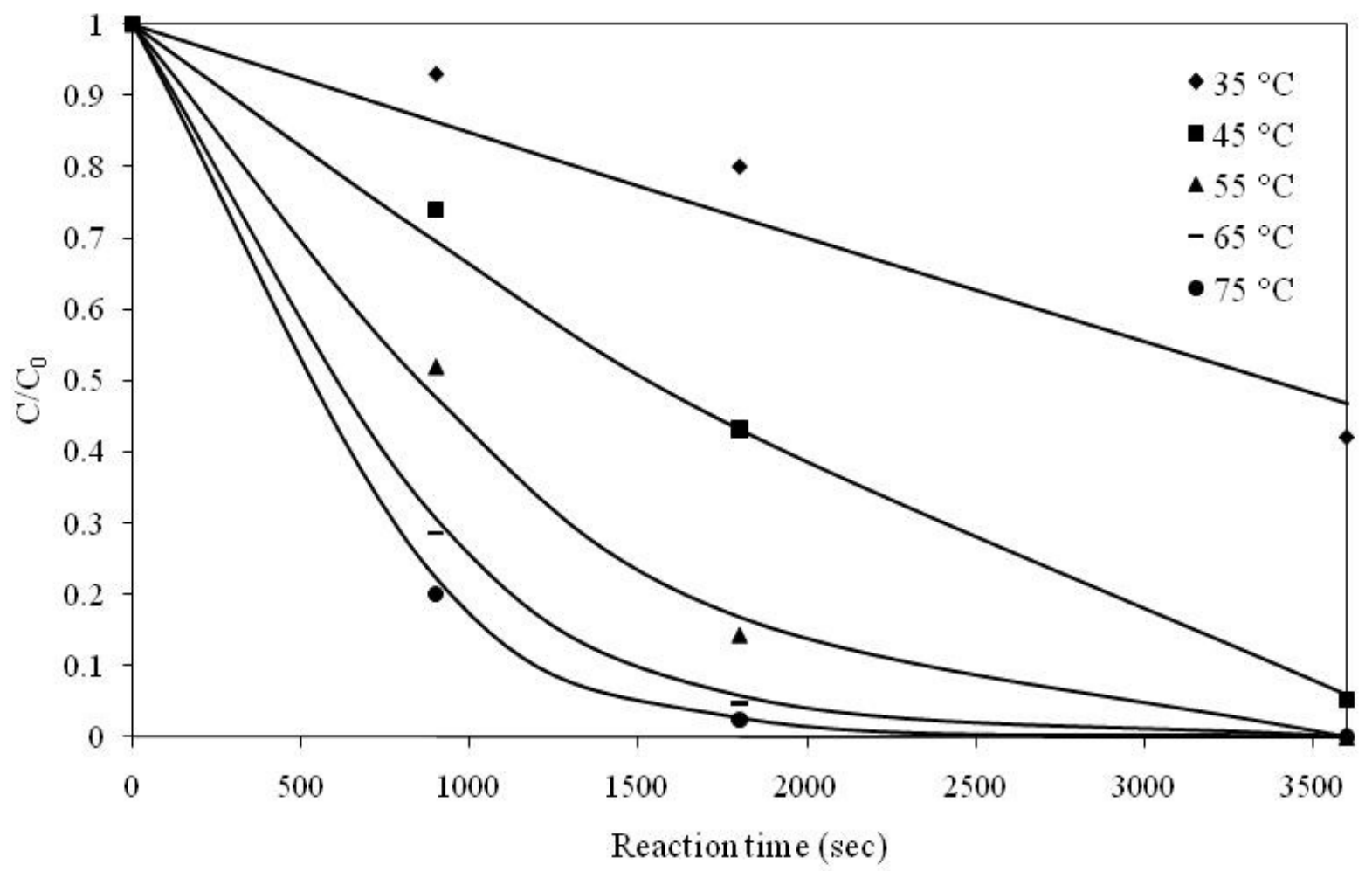

Figure 5.7 Effect of temperature on hypochlorite depletion (0.5 molar OCl-, 3 grams chalcopyrite, $\mathrm{pH} 13.15$ )

Figure 5.7 demonstrates the depletion of hypochlorite concentration from the same series of experiments as for Figure 5.6. The solid lines in Figure 5.6 are the fitting lines for a kinetic model which will be discussed later. Also, the solid lines in Figure 5.7 are the fitting lines with a rate equation which will be discussed later as well. 
Using the data of Figures 5.6 and 5.7, the hypochlorite consumption ratio at 1 hour was calculated and is presented in Figure 5.8. This ratio is defined as the number of moles of hypochlorite consumed to leach one mole of chalcopyrite.

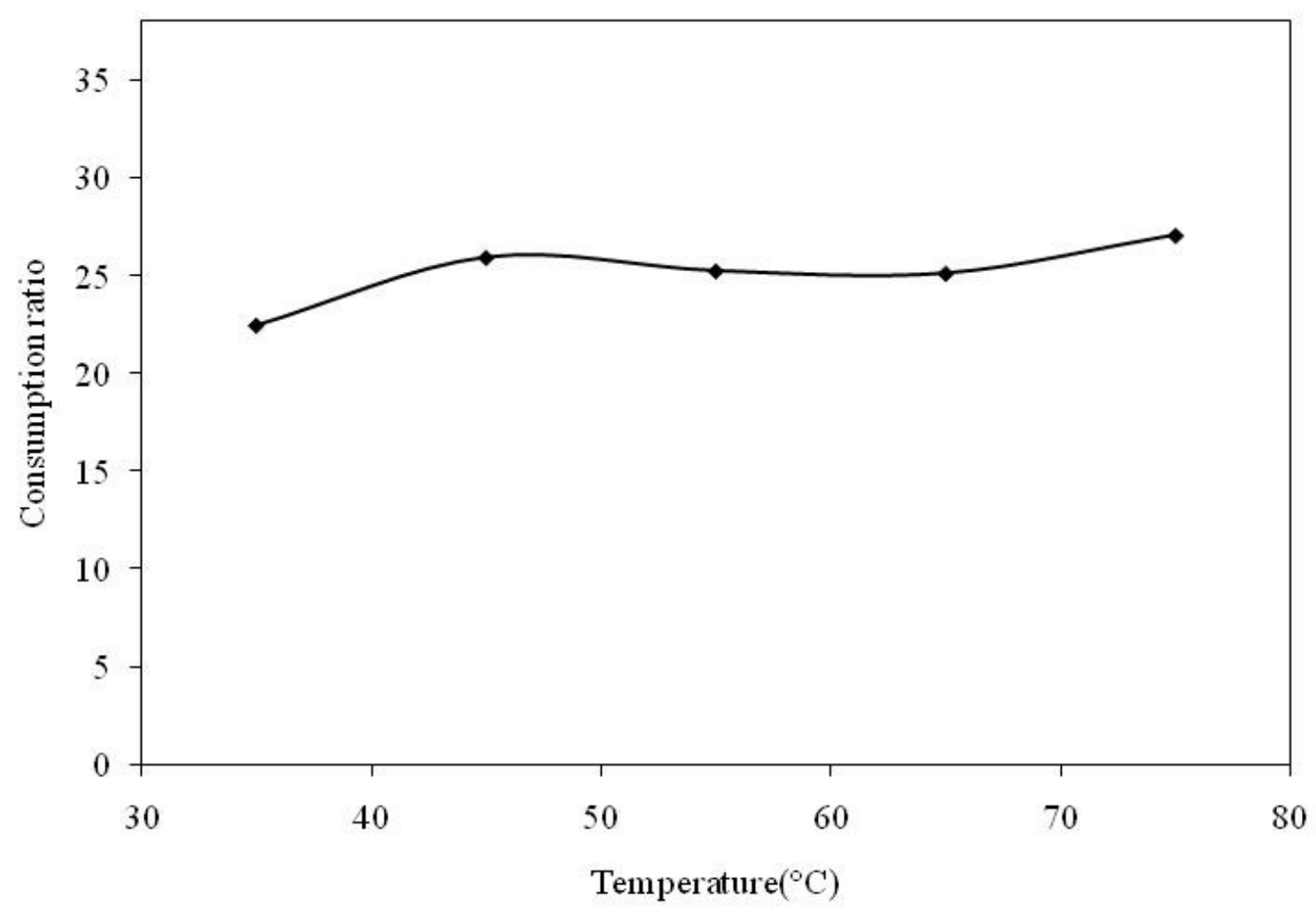

Figure 5.8 Effect of temperature on reagent consumption ratio $\left(55^{\circ} \mathrm{C}, 3\right.$ grams chalcopyrite, initial $\mathrm{pH}$ 13.15).

As shown in Figure 5.8, the consumption ratio is rather insensitive to temperature. It may be due to the fact that the hypochlorite depletion increases as the temperature increases, but the number of moles of chalcopyrite leached also increases, maintaining the ratio at roughly the same level. From Figure 5.8, the average consumption ratio is found to be around 25 which is about 3 times more than the stoichiometric ratio, if the reaction were to take place according to reaction 3.7 for which the stoichiometric ratio is 8.5 . 


\subsection{Effect of Hypochlorite concentration:}

The effect of initial concentration of hypochlorite on leaching conversion of chalcopyrite is shown in Figure 5.9. The experimental conditions are hypochlorite concentration 0.2-0.85 molar and 3 grams chalcopyrite at a temperature of $55^{\circ} \mathrm{C}$ and $\mathrm{pH} 13.15$.

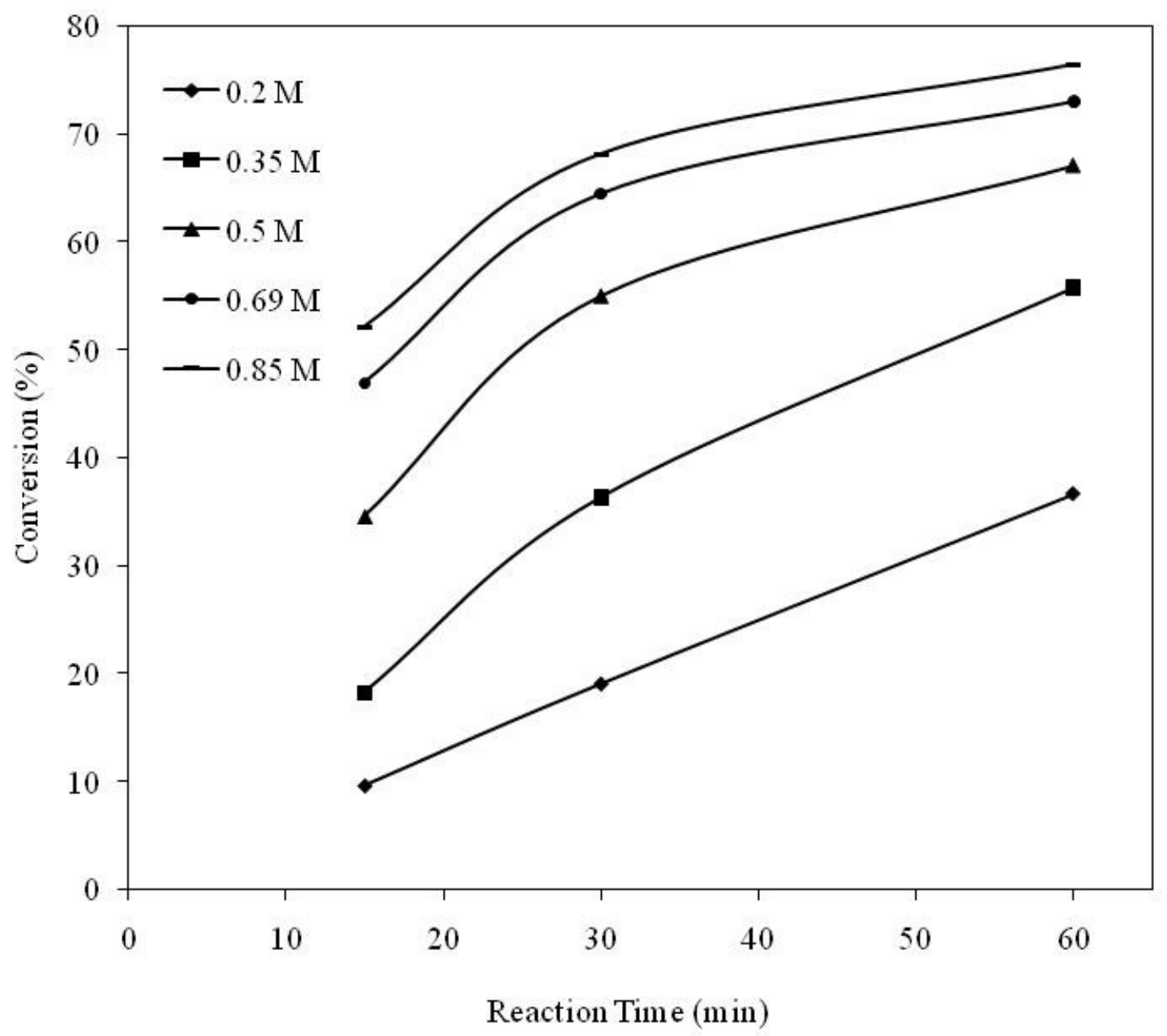

Figure 5.9 Effect of hypochlorite concentration on chalcopyrite leaching conversion $\left(55^{\circ} \mathrm{C}, 3\right.$ grams chalcopyrite, $\mathrm{pH}$ 13.5). 
The leaching conversion increases with increasing initial hypochlorite concentration up to 0.5 molar and then not much upon further increase. The conversion is $36.4 \%$ at 0.2 molar of hypochlorite and increases to $76.4 \%$ at 0.85 molar in 1 hour. The cupric oxy-anion concentration was also detected during this series, and was found to be $0.21 \mathrm{ppm}$ at 0.2 molar and $0.44 \mathrm{ppm}$ at 0.85 molar. Figure 5.10 demonstrates the depletion of hypochlorite concentration from the same series of experiments as for Figure 5.9.

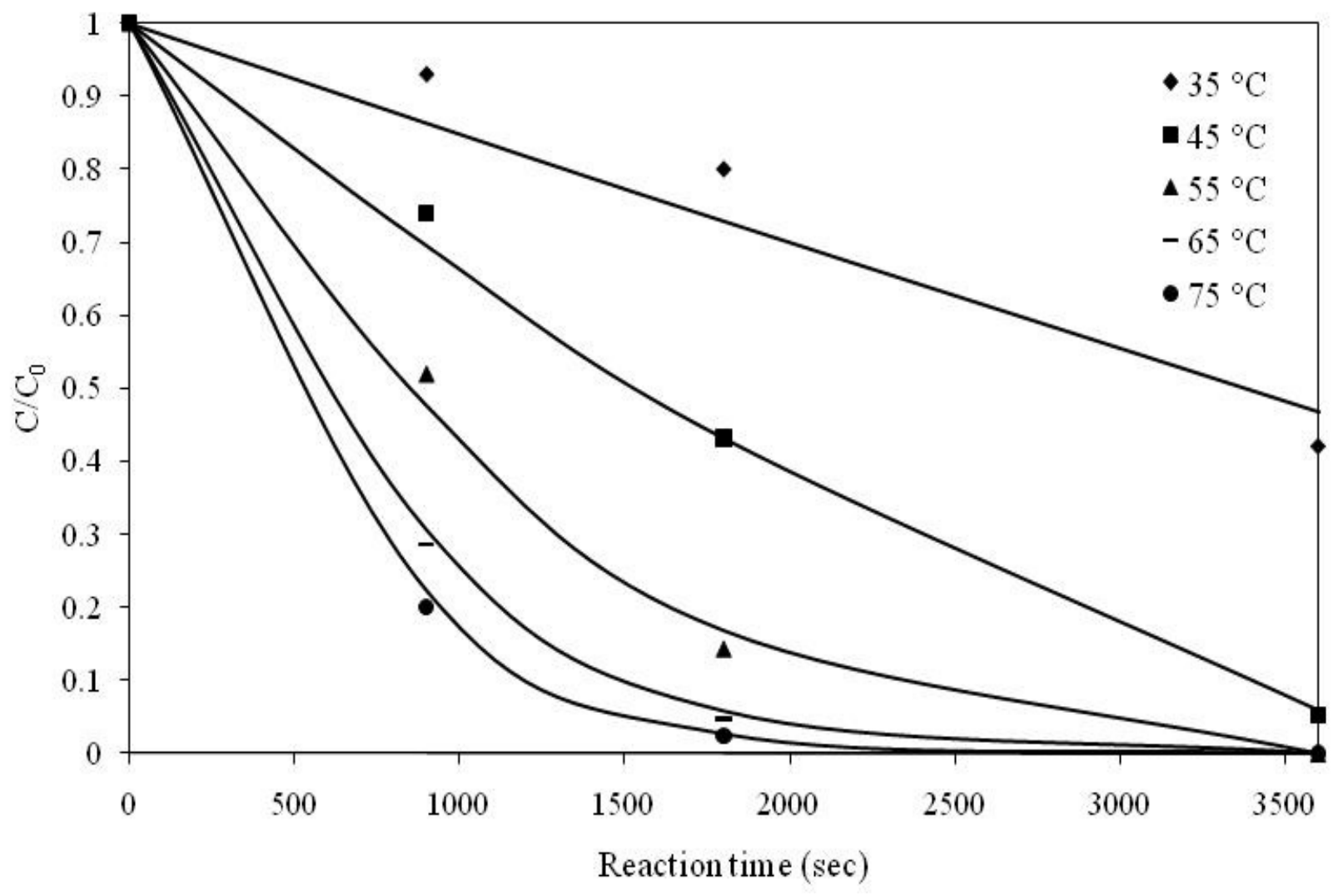

Figure 5.10 Depletion of hypochlorite concentration at various initial concentrations $\left(55{ }^{\circ} \mathrm{C}, 3\right.$ grams chalcopyrite, initial $\mathrm{pH} 13.15$ ). 


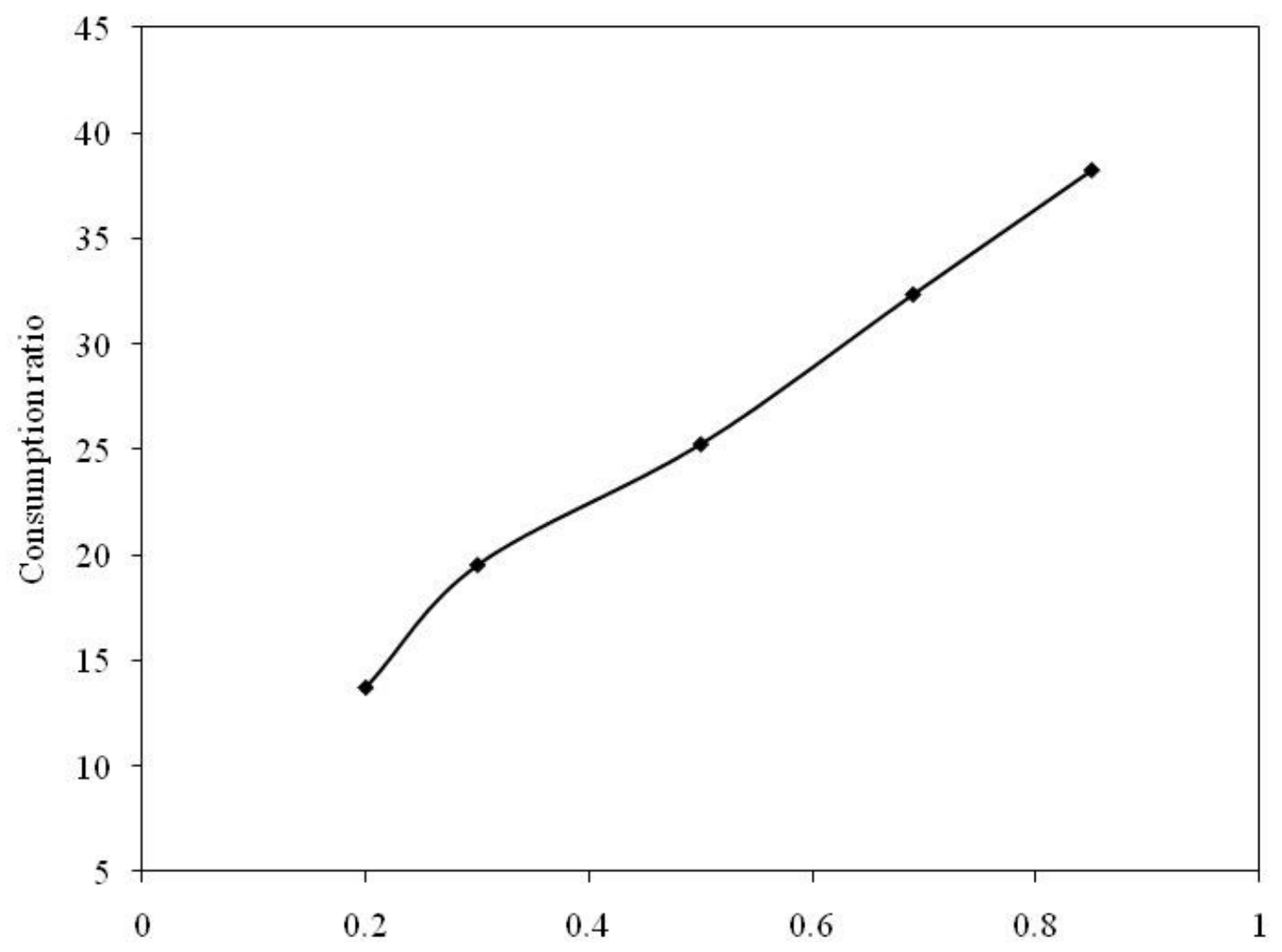

Hypochlorite concentration (M)

Figure 5.11 Effect of initial hypochlorite concentration on reagent consumption ratio at 60 minutes $\left(55^{\circ} \mathrm{C}, 3\right.$ grams chalcopyrite, initial $\left.\mathrm{pH} 13.15\right)$.

Using the data of Figures 5.9 and 5.10, the hypochlorite consumption ratio at 1 hour is calculated and plotted in Figure 5.11. As shown in Figure 5.11, the consumption ratio is an almost linear function with respect to the initial hypochlorite concentration. It varies from 13.7 at 0.2 molar of hypochlorite to 38.2 at 0.85 molar. When the concentration is 0.2 molar, much of the hypochlorite depletion may be due to the leaching of the mineral; however, as the concentration increases to 0.85 molar, the depletion of hypochlorite increases disproportionately to the number of moles of chalcopyrite leached. The reason is not known at this time. 


\subsection{Effect of Chalcopyrite dosage:}

The next series of experiments conducted to study the effect of chalcopyrite dosage with 1-10 grams of chalcopyrite in $500 \mathrm{ml}$ solution at $55^{\circ} \mathrm{C}$, initial $\mathrm{pH} 13.15$ and 1 hour. The results are demonstrated in Figure 5.12. The leaching conversion of chalcopyrite to cupric oxide is $78.6 \%$ with 1 gram of the mineral but decreases to $40.0 \%$ with 10 grams of the mineral

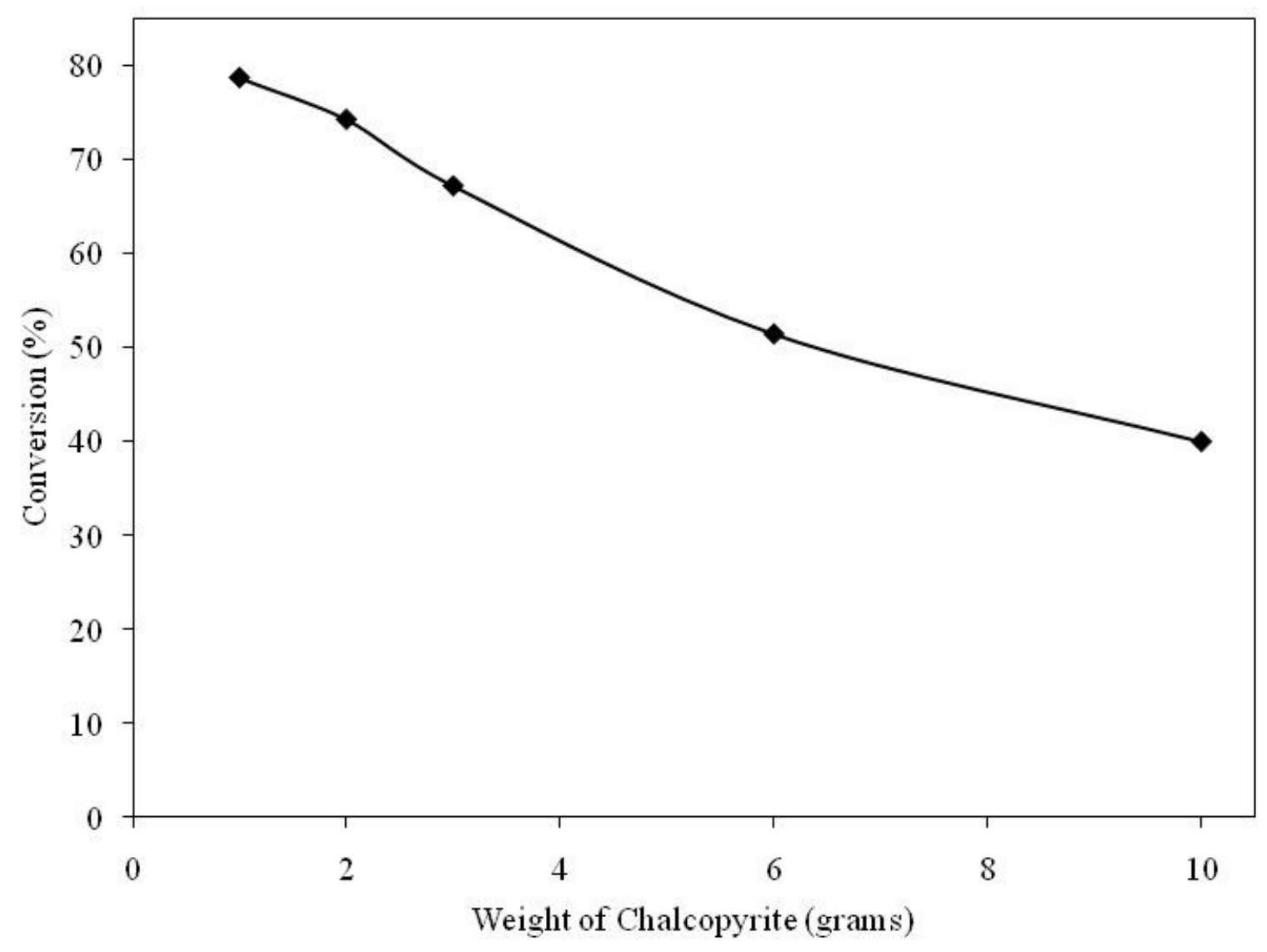

Figure 5.12 Effect of chalcopyrite dosage on leaching conversion at 60 minutes $\left(55{ }^{\circ} \mathrm{C}, 0.5\right.$ molar OCl-, initial pH 13.15). 


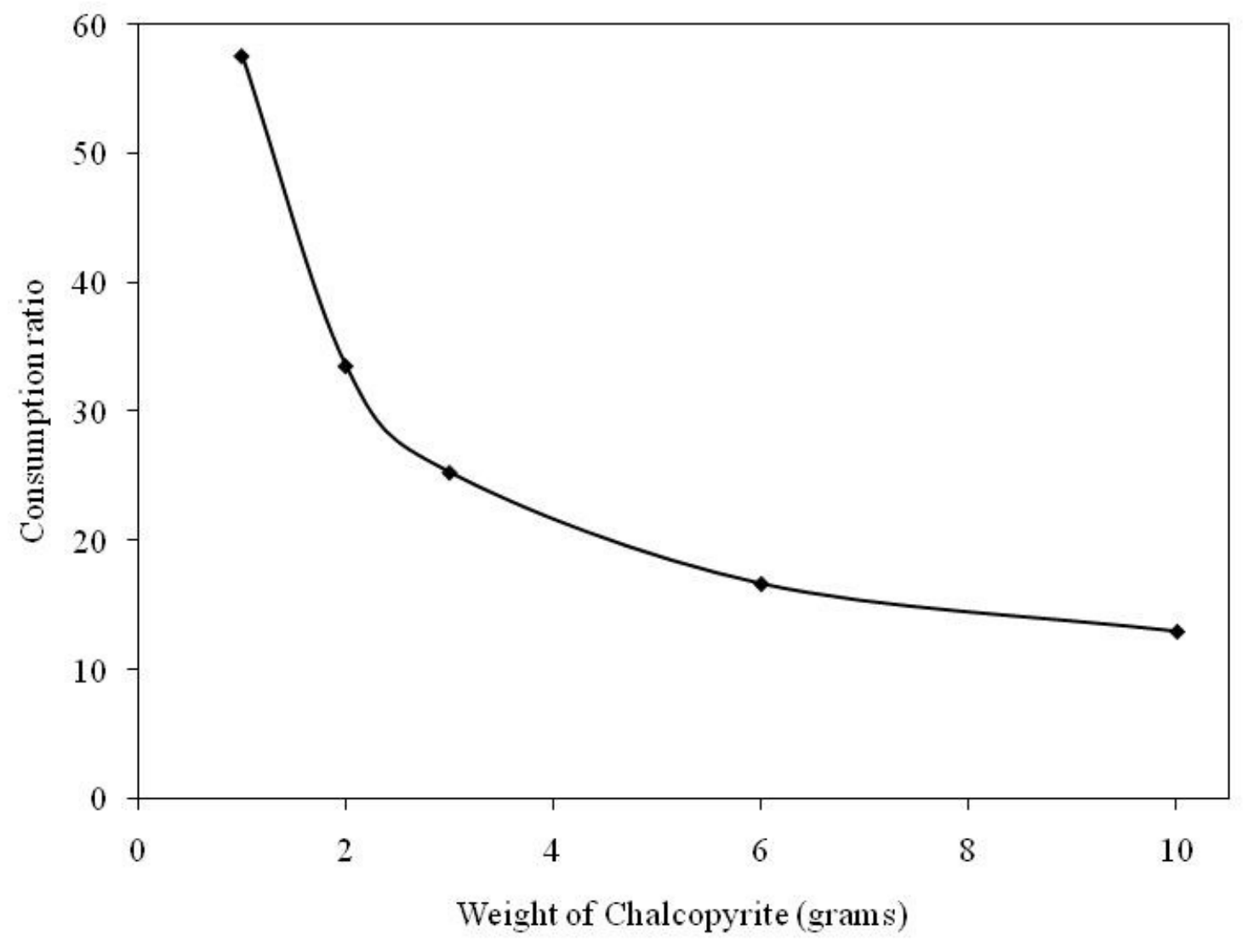

Figure 5.13 Effect of chalcopyrite dosage on hypochlorite consumption ratio at 60 minutes (55 ${ }^{\circ} \mathrm{C}, 0.5$ molar $\mathrm{OCl}^{-}$, initial $\mathrm{pH}$ 13.15).

. Figure 5.13 shows hypochlorite consumption ratio from the same series of experiments as for Figure 5.12. The consumption ratio is as high as 57.6 with 1 gram of the mineral and decreases to 12.9 with 10 grams of the mineral. 


\subsection{Discussion:}

\section{A. Optimum Leaching Conditions}

As shown in Figure 5.11, hypochlorite consumption ratio varies from 13.7 at 0.2 molar of hypochlorite to 38.2 at 0.85 molar. The ratio of available hypochlorite to leach one mole of chalcopyrite at 0.2 molar is 6.12 and that at 0.85 molar is 27.53 . These values correspond to 0.72 and 3.24 times as much as the stoichiometric factor, respectively. Thus, in order to minimize the hypochlorite consumption ratio, the available concentration should be lower or equal to its stoichiometric value. Again, as shown in Figure 5.13, the hypochlorite consumption ratio is as high as 57.6 with 1 gram of the mineral and decreases to 12.9 with 10 grams of the mineral. The ratio of available hypochlorite to leach one mole of chalcopyrite with 1 gram mineral is 45.88 and that with 10 grams is 4.59 . These values correspond to 5.4 and 0.54 times as much as the stoichiometric factor, respectively.

Again, in order to minimize the hypochlorite consumption ratio, the solid dosage should be increased so that hypochlorite concentration should become lower than its stoichiometric value. However, in determining the optimum conditions in terms of hypochlorite concentration and solid dosage, the leaching conversion of chalcopyrite to cupric oxide also should be considered because it is directly related to how many leaching stages should be applied to complete the leaching. Thus, it is not a simple matter to determine the optimum conditions because there should be compromise between these two factors. However, a first approximation is possible as follows: The temperature could be $55^{\circ} \mathrm{C}$ because the conversion is near the maximum value at this temperature and the cupric oxy-anion concentration is small at $0.3 \mathrm{ppm}$. The $\mathrm{pH}$ should be 13.2. The optimum conditions in terms of hypochlorite concentration and solid 
dosage could be determined with the same stoichiometric factor of 0.54 when the solid dosage was 10 grams. If this stoichiometric factor is adopted and the concentration of hypochlorite is 1.8 molar, the solid percent is determined to be 7.2. 


\section{B. Step wise addition:}

A new leaching scheme was devised in this study to achieve complete conversion. An experiment was carried out in the same way as other experiments in this study, but its reaction time was extended by adding hypochlorite stock solution stepwise every 40 minutes for three times. The experiment was initiated with $10 \mathrm{~g}$ chalcopyrite at 0.5 molar hypochlorite, $\mathrm{pH} 13.2$ and $55^{\circ} \mathrm{C}$. At 40 minutes, a 50-ml sample was withdrawn from the reactor and filtered, and immediately $100 \mathrm{ml}$ hypochlorite stock solution was withdrawn from the separate 1-liter reactor maintained at $55^{\circ} \mathrm{C}$ and poured into the leaching reactor. This addition continued for two more times. The conversions were determined as before. The result is depicted in Figure 5.14.

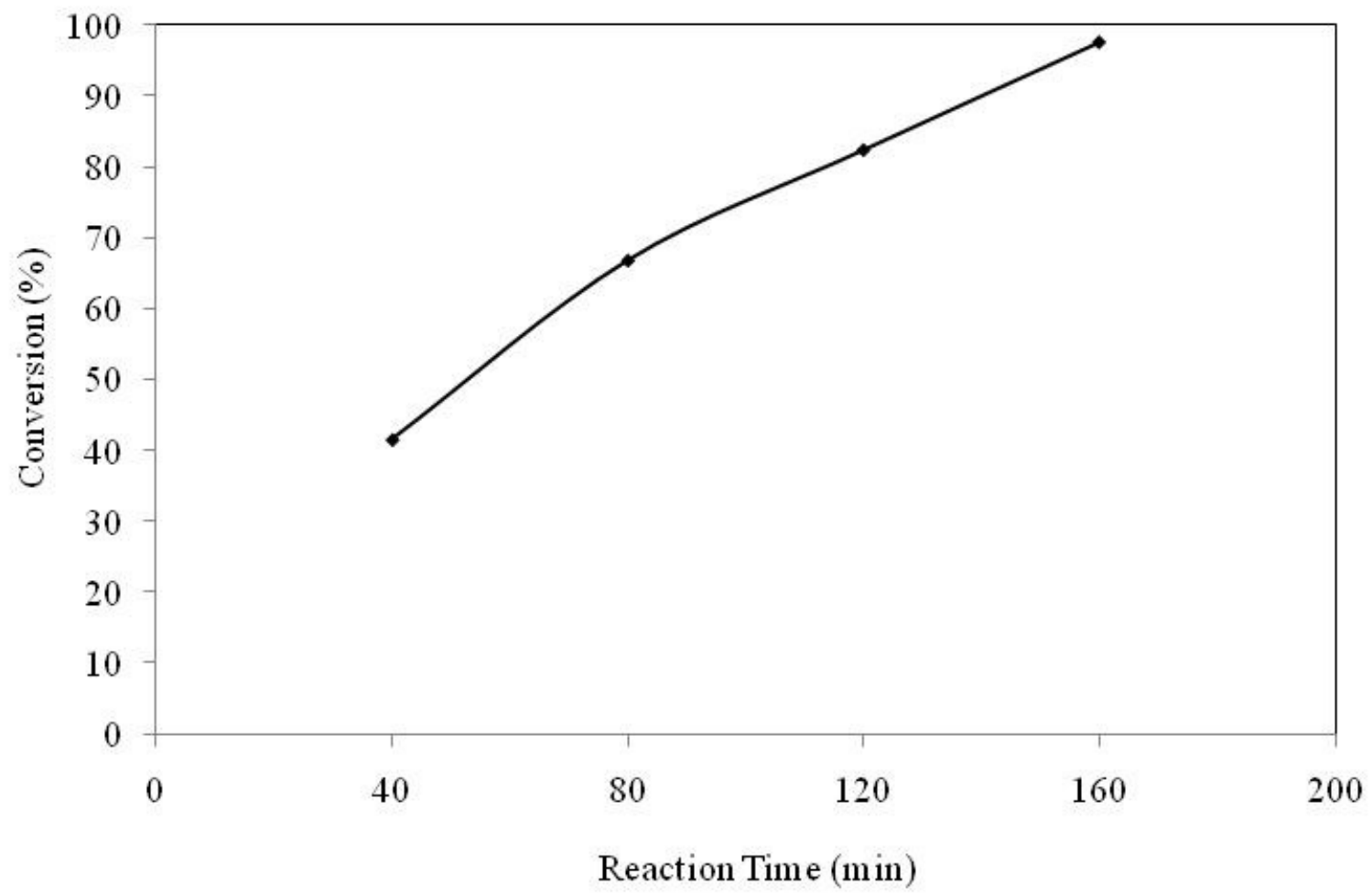

Figure 5. 14 Leaching conversion of chalcopyrite with stepwise addition of hypochlorite $\left(55^{\circ} \mathrm{C}\right.$, $\mathrm{pH}$ 13.2, 10 grams chalcopyrite). 
It is observed that the conversion is almost completed in 160 minutes. However, a problem seems to come from application of excessive reagent amounts of hypochlorite and sodium hydroxide. In this experiment, the amounts of hypochlorite and sodium hydroxide at 1.9 and 2.6 times, respectively, as much as stoichiometric amounts according to reaction 2.18 were used. The hypochlorite consumption ratio was calculated at 160 minutes and it was 16.8 which are almost twice as much as the stoichiometric amount. Thus, this leaching scheme with stepwise addition should be optimized on the concentrations of hypochlorite and sodium hydroxide, and solid dosage to achieve the complete conversion and, at the same time, to reduce the hypochlorite consumption ratio as small as possible toward its stoichiometric value of 8.5 in order to determine the technical feasibility. 


\section{Kinetic Models}

In this study, the leaching rate of chalcopyrite was analyzed by fitting the rate curves using a shrinking core model based on chemical reaction control. According to the model the leaching rate of chalcopyrite may be given as

$\frac{d n}{d t}=-\frac{4 \pi r^{2}}{\phi} C^{p} k$

Where, $\mathrm{n}=$ number of moles of unleached chalcopyrite in a particle at time $\mathrm{t}$,

$\mathrm{r}=$ radius of unreacted core in a particle $(\mathrm{m})$,

$\mathrm{C}=$ concentration of hypochlorite at time $\mathrm{t}\left(\mathrm{mol} / \mathrm{m}^{3}\right)$,

$\mathrm{k}=$ rate constant $\left(\left(\mathrm{m}^{3 \mathrm{p}} / \mathrm{mol}^{\mathrm{p}-1}\right) \cdot \mathrm{sec}\right)$,

$\mathrm{p}=$ reaction order with respect to $\mathrm{C}$, and

$\phi=$ sphericity of chalcopyrite particle.

Equation (5.1) may be further simplified as:

$\frac{d F}{d t}=\frac{3 V C^{p} k_{1}}{r_{0}}(1-F)^{2 / 3}$

Where, $\mathrm{F}=$ fraction of chalcopyrite leached or leaching conversion into cupric oxide, $\mathrm{V}=$ chalcopyrite molar volume $\left(\mathrm{m}^{3} / \mathrm{mol}\right)$,

$\mathrm{k}_{1}$ is $\mathrm{k} / \phi$ and

$\mathrm{r}_{\mathrm{o}}=$ original radius of chalcopyrite particle $(\mathrm{m})$. 
The hypochlorite concentration is a time-dependent term, and should be available for numerical integration of Equation (5.2). A mathematical relationship for the depletion of hypochlorite concentration vs time was obtained by fitting the experimental data as shown in Figure 5.7 with an integrated equation of a $\mathrm{q}^{\text {th }}$ order rate equation, which is given by

$\frac{d C}{d t}=-k_{2} C^{q}$

Where, $\mathrm{q}$ is the reaction order with respect to hypochlorite concentration and

$\mathrm{k}_{2}$ is the rate constant.

Equation (5.3) is integrated to

$\frac{1}{C^{q-1}}-\frac{1}{C_{0}{ }^{q-1}}=(q-1) k_{2} t$

where $\mathrm{C}_{\mathrm{o}}$ is the initial concentration of hypochlorite $\left(\mathrm{mol} / \mathrm{m}^{3}\right)$.

The values of $\mathrm{q}$ and $\mathrm{k}_{2}$ were selected by fitting the experimental data at 35 to $75{ }^{\circ} \mathrm{C}$ as shown in Figure 5.7, and are given in Table 5.2 together with $\mathrm{k}_{1}$ values which will be obtained later. One can see that from the figure that the fitting for the depletion of hypochlorite with Equation (5.4) is generally good with the exception at $35^{\circ} \mathrm{C}$.

The numerical integration of Equation (5.2) was carried out using the Matlab ode45 function. The value of $\mathrm{p}$, the reaction order with respect to hypochlorite concentration was determined by a trial-and-error method. Two values of $\mathrm{p}$ were tried. They were 1 and 0.5 , or of first and half order reactions. The values of $\mathrm{q}$ and $\mathrm{k}_{2}$ at $55{ }^{\circ} \mathrm{C}$ from Table 5.2 were used in the computation. Then $\mathrm{k}_{1}$ values were selected for their best fitting by a trial-and error method. 
Table $5.2 \mathrm{k}_{1}, \mathrm{q}$ and $\mathrm{k}_{2}$ values.

\begin{tabular}{|c|c|c|c|c|c|}
\hline Temperature & $35^{\circ} \mathrm{C}$ & $45^{\circ} \mathrm{C}$ & $55^{\circ} \mathrm{C}$ & $65^{\circ} \mathrm{C}$ & $75^{\circ} \mathrm{C}$ \\
\hline $\begin{array}{c}\mathrm{k}_{1}, \\
\mathrm{~m}^{-0.5} \mathrm{~mol}^{0.5} \mathrm{~s}\end{array}$ & $1.48 \times 10^{-6}$ & $3.54 \times 10^{-6}$ & $5.7 \times 10^{-6}$ & $8.5 \times 10^{-6}$ & $9.12 \times 10^{-6}$ \\
\hline $\mathrm{q}$ & 0.95 & 0.95 & 0.95 & 0.95 & 0.95 \\
\hline $\mathrm{k}_{2}$, & 0.0002 & 0.00065 & 0.0012 & 0.002 & 0.0024 \\
$\left(\mathrm{~mol} / \mathrm{m}^{3}\right)^{1-\mathrm{q}} \mathrm{s}^{-1}$ & & & & & \\
\hline
\end{tabular}

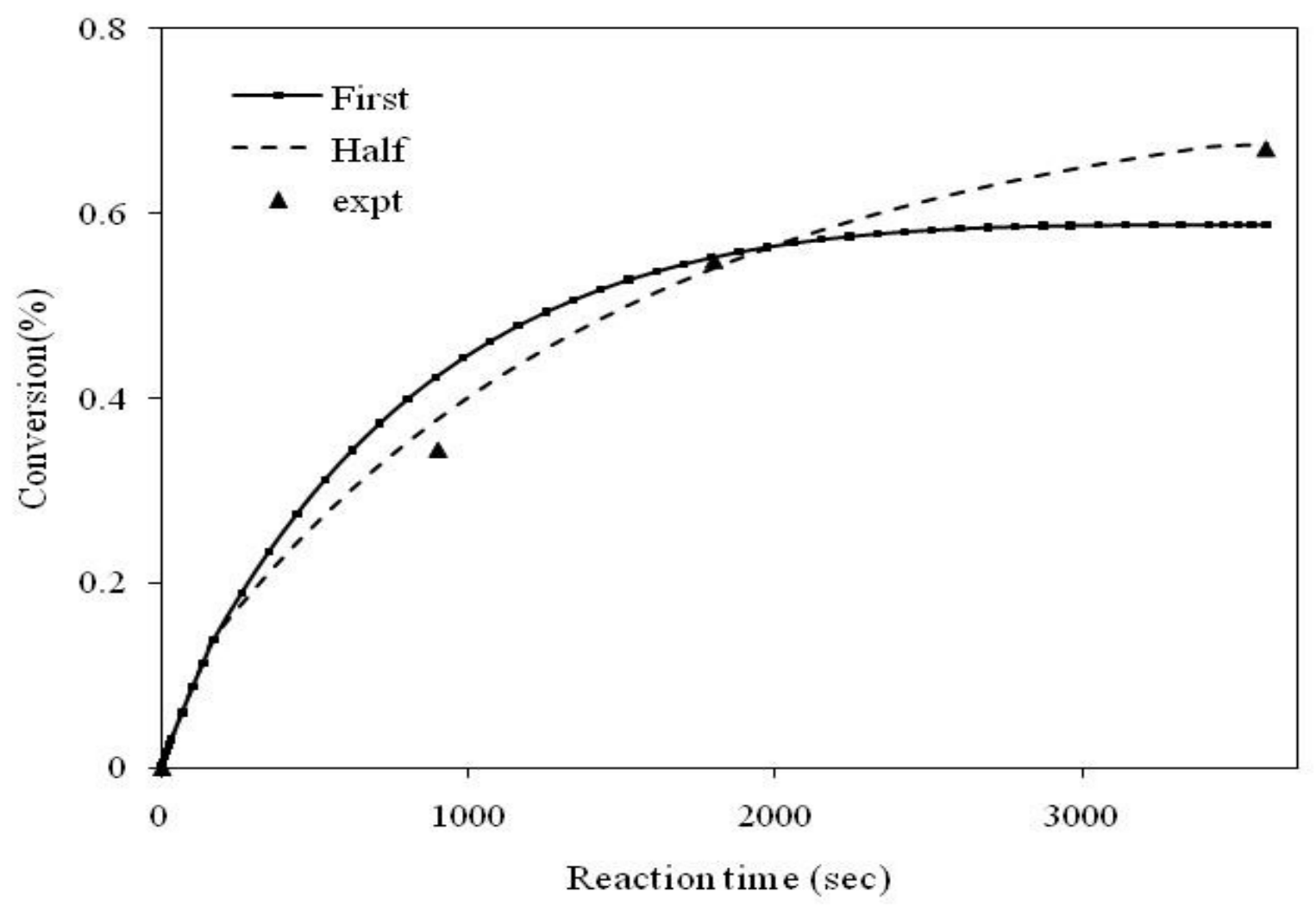

Figure 5.15 Comparison of surface reaction control model fitting for first and half orders with respect to hypochlorite concentration $\left(55^{\circ} \mathrm{C}, 3\right.$ grams chalcopyrite, initial $\left.\mathrm{pH} 13.15\right)$.

Figure 5.15 compares the experimental data with each computed leaching curve using the two models of first and half order reactions. One can see that the model with the half order 
reaction better fits the experimental data than that with the first order dependence. Then the model with the half order dependence was used to fit the experimental data at other temperatures of $35,45,65$, and $75^{\circ} \mathrm{C}$. The $\mathrm{k}_{1}$ values at these temperatures were selected for their best fitting of the experimental data by a trial-and error method. The fitting including that of $55{ }^{\circ} \mathrm{C}$ is shown in Figure 5.6. It appears that the fitting is generally good.

This model resembles those of ferric chloride leaching ${ }^{12}$ and ammonia leaching ${ }^{19}$ in that the three models are based on the surface reaction control and also half-order dependence with respect to the reagent concentrations. The half-order reaction is frequently observed on electrochemical reactions when the rate is controlled by chemical reaction. This half-order dependence on the hypochlorite concentration may verify that this leaching reaction is an electrochemical reaction as previously presented.

An Arrhenius plot is made with the $\mathrm{k}_{1}$ values and shown in Figure 5.16. Only four $\mathrm{k}_{1}$ values from 35 to $65{ }^{\circ} \mathrm{C}$ given in Table 5.2 were used to calculate the activation energy. However, the $\mathrm{k}_{1}$ value at $75{ }^{\circ} \mathrm{C}$ does not seem to be on the straight line. It appears that at this temperature, the rate controlling step may change to diffusion controlling step or mixed kinetics where the diffusion is a great part of it. 


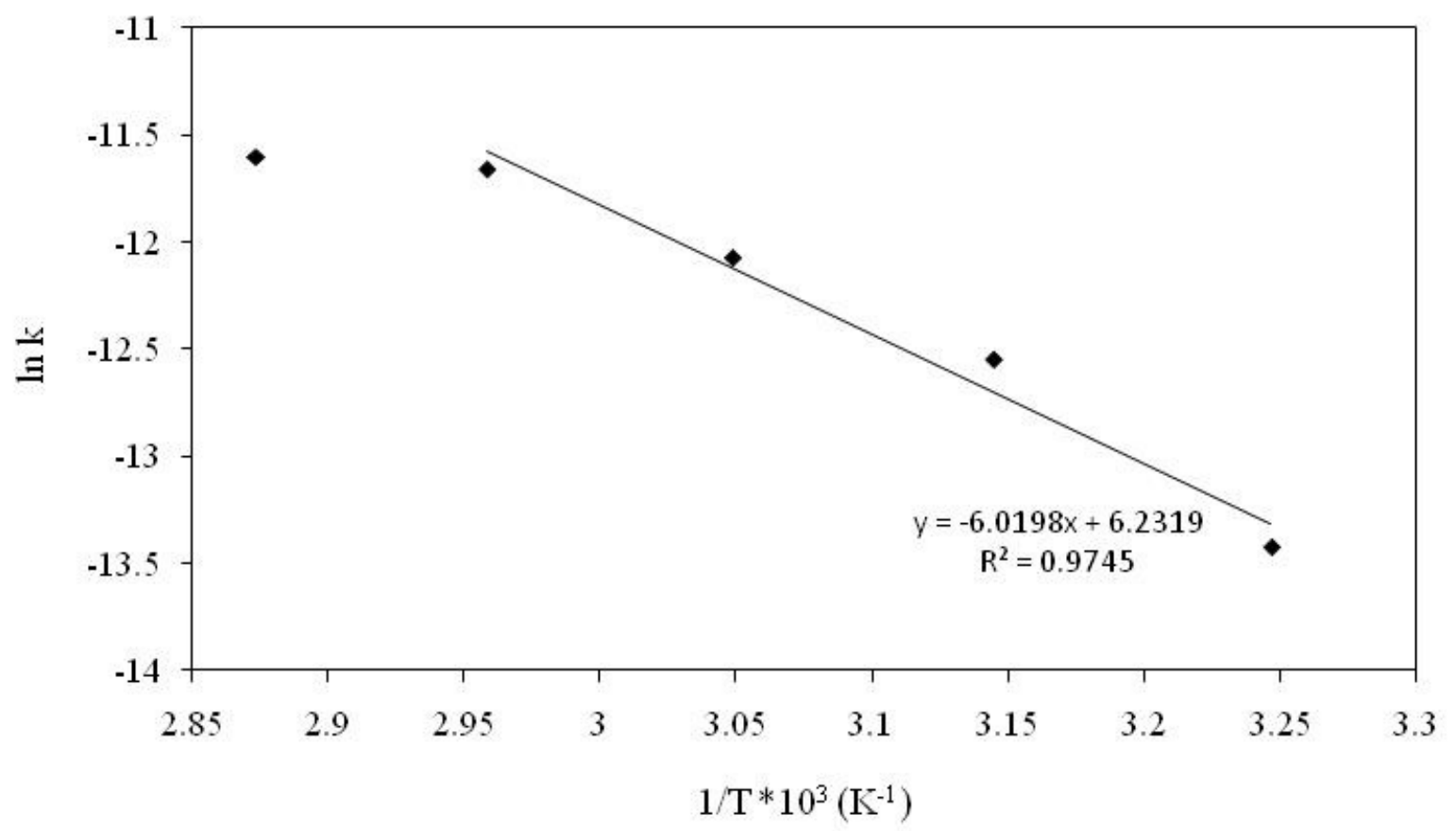

Figure 5.16 Arrhenius plot for chalcopyrite leaching with hypochlorite $\left(0.5\right.$ molar $\mathrm{OCl}^{-}$, 3grams chalcopyrite, initial $\mathrm{pH} 13.15$ )

However, more experiments above this temperature are needed to verify this trend, and as mentioned previously, those experiments are difficult to conduct because the hypochlorite concentration tended to decrease too fast to analyze accurately. From the slope of the straight line in the Arrhenius plot (Figure 5.16), the activation energy was calculated and this was found to be $50.2 \mathrm{~kJ} / \mathrm{mol}(12.0 \mathrm{kcal} / \mathrm{mol})$. The magnitude of this activation energy verifies the chemical reaction controlling mechanism previously assumed ${ }^{25}$. 


\section{Conclusions}

The present study reveals that the chalcopyrite can be leached much faster with sodium hypochlorite than with the conventional reagents such as ferric sulfate or ferric chloride. The leaching conversion reaches about $68 \%$ in 1 hour at $65{ }^{\circ} \mathrm{C}$ and 0.5 molar of hypochlorite. The conversion shows a maximum at $\mathrm{pH} 13.15-13.20$ and also at $65^{\circ} \mathrm{C}$ in their respective series.

Hypochlorite consumption ratio reached 57.6 when the solid dosage was 1 gram in 500 $\mathrm{ml}$ at $55{ }^{\circ} \mathrm{C}$ and 0.5 molar of hypochlorite which is much higher than its stoichiometric value of 8.5. The ratio decreased to 12.9 , when the chalcopyrite weight was increased to 10 grams.

The optimum leaching conditions were proposed considering primarily the hypochlorite consumption ratio and leaching conversion. The optimum conditions are $55{ }^{\circ} \mathrm{C}, \mathrm{pH} 13.2,7.2$ solid weight $\%$ and 1.8 molar of hypochlorite.

Leaching curves were fitted well by a shrinking core model based on chemical reaction control. A half order reaction with respect to hypochlorite concentration was determined in the model. The activation energy of $50.2 \mathrm{~kJ} / \mathrm{mol}(12.0 \mathrm{kcal} / \mathrm{mol})$ was found.

A leaching scheme was identified in which $98 \%$ of chalcopyrite was leached with adding hypochlorite stock solution stepwise in less than three hours. 


\section{Areas requiring additional study:}

As seen from the above discussion, many aspects of the reaction between chalcopyrite and hypochlorite are fairly resolved, or require only moderate clarification. However, there are still some important topics which need to be addressed. The following areas require additional study,

1. It would be appropriate to conduct kinetic studies at higher temperatures to confirm the reaction mechanism.

2. In order to enhance the leaching rate of chalcopyrite with hypochlorite it would be appropriate to conduct more experiments in presence of copper ions, ferrous ions or other catalysts and promoters.

3. Conduct more experiments to study the reagent loss by other side reactions.

4. To study the economics of this process compared with other process. 


\section{References}

1. Prasad, S. and Pandey, B. D.; Minerals Engineering, Vol. 11, No. 8, 1998, pp.763-781.

2. http://www.epa.gov/airmarkets/progsregs/arp/laws.html.

3. Munoz, P.B.; Miller, J. D.; and Wardsworth, M.E.; Met. Trans B, Vol.10B, June 1979, pp.149-158.

4. Filippou, D.; German, P.; Grammatikopoulos, T.; Mineral Processing and Extractive Meta. II, Rev, 28, 2007, pp.247-298.

5. Edelstein, D. L.; “'Copper: Statistics and Information.', US Geological Survey 2004, http://minerals.usgs.gov/minerals/pubs/commodity/copper/\#pubs.

6. International Copper Study Group, 2006, “Markets at a glance.”, http://www.icsg.org.

7. International Copper Study Group, 2007, “Statistical Yearbook.”, http://www.icsg.org.

8. Bartos, P. J.; SX-EW Copper and Technology Cycle, Resources Policy, Vol. 28, 2002, pp 85-94.

9. Prater, J. D; Queneau P. B; Hudson, T. J; Journal of Metals, Vol. 22, 1970, pp. 23-27.

10. Dutrizac, J. E.; Met. Trans. B, Vol. 12B, June 1981, pp.149-158.

11. Dutrizac, J. E.; Hydrometallurgy 29, 1992, pp. 1-45.

12. Palmer, B. R.; Nebo, C. O.; Rau, M. F.; and Fuerstenau, M. C.; Met. Trans. B, Vol. 12B, September 1981, pp.595-601.

13. Bonan, M.; Demarthe, J. M.; Renon, H.; and Baratin, F.; Met. Trans. B, Vol. 12B, June 1981, pp. 269-274.

14. Lundstrom, M.; Aromaa, J.; Forsen, O.; Hyvarinen, O.; Barker, M. H; Hydrometallurgy 77, 2005, pp. 89-95.

15. Lu, Z. Y.; Jeffrey, M. I.; Lawson, F.; Hydrometallurgy, Vol. 56, 2000, pp. 189-202. 
16. Kruesi, P.R.; Mining Congress Journal, Vol. 23, 1971, pp. 25.

17. Kruesi, P. R.; Allen, E. S.; Lake, J. L.; Canadian Mining, Metallurgy Bull., Vol. 66, 1973, pp. 81-87.

18. Anon; Engineering and Mining Journal, Vol. 178, 1977, pp. 33.

19. Kuhn, M. C.; Arbitor, N.; Kling, H.; Canadian Mining, Metallurgy Bull., Vol. 67, 1974, pp. 62-73.

20. Hyvarinen, O.; Hamalainen, M.; Leimala, R.; Chloride Metallurgy, 2002, pp. 609-612.

21. Dixon, D. G.; Mayne, D. D.; Baxter, K. G.; Canadian Metallurgical Quarterly, Vol. 47, No. 3, 2008, pp. 327-336.

22. Garrels, R. M.; Solutions, Minerals, and Equilibrium, Freeman, Cooper and Company, San Francisco, 1965, pp. 407.

23. Cho, E. H.; Metallurgical Transactions B, Vol. 18 B, June 1987, pp. 315-323.

24. Garlapalli, R.; Cho, E. H.; and Yang, R. Y. K; Hydrometallurgy 2008, Proceedings of the Sixth International Symposium, edited by C. A. Young, P.R. Taylor, C. G. Anderson, and Y. Choi, SME, 2008, pp. 653-657.

25. Wadsworth, M. E.; Rate processes of Extractive Metallurgy, edited by H. Y. Hong and M. E. Wadsworth, Plenum Press, 1979, pp. 135. 